Prepared in cooperation with the Bureau of Land Management

\title{
Land-Cover Mapping of Red Rock Canyon National Conservation Area and Coyote Springs, Piute-Eldorado Valley, and Mormon Mesa Areas of Critical Environmental Concern, Clark County, Nevada
}

Scientific Investigations Report 2014-5076 
Cover. Ferocactus cylindraceous Limestone Bedrock Shrubland Alliance at sample 2004 in Coyote Springs Area of Critical Environmental Concern. Photo by David A. Charlet. 


\section{Land-Cover Mapping of Red Rock Canyon National Conservation Area and Coyote Springs, Piute-Eldorado Valley, and Mormon Mesa Areas of Critical Environmental Concern, Clark County, Nevada}

By J. LaRue Smith, Nancy A. Damar, David A. Charlet, and Craig L. Westenburg

Prepared in cooperation with the Bureau of Land Management

Scientific Investigations Report 2014-5076 


\title{
U.S. Department of the Interior \\ SALLY JEWELL, Secretary
}

\author{
U.S. Geological Survey \\ Suzette M. Kimball, Acting Director
}

U.S. Geological Survey, Reston, Virginia: 2014

For more information on the USGS - the Federal source for science about the Earth, its natural and living resources, natural hazards, and the environment, visit http://www.usgs.gov or call 1-888-ASK-USGS.

For an overview of USGS information products, including maps, imagery, and publications, visit http://www.usgs.gov/pubprod

To order this and other USGS information products, visit http://store.usgs.gov

Any use of trade, firm, or product names is for descriptive purposes only and does not imply endorsement by the U.S. Government.

Although this information product, for the most part, is in the public domain, it also may contain copyrighted materials as noted in the text. Permission to reproduce copyrighted items must be secured from the copyright owner.

Suggested citation:

Smith, J.L., Damar, N.A., Charlet, D.A., and Westenburg, C.L., Land-cover mapping of Red Rock Canyon National Conservation Area and Coyote Springs, Piute-Eldorado Valley, and Mormon Mesa Areas of Critical Environmental Concern, Clark County, Nevada: U.S. Geological Survey, Scientific Investigations Report 2014-5076, 42 p., http://dx.doi.org/10.3133/sir20145076.

ISSN 2328-0328 (online) 


\section{Contents}

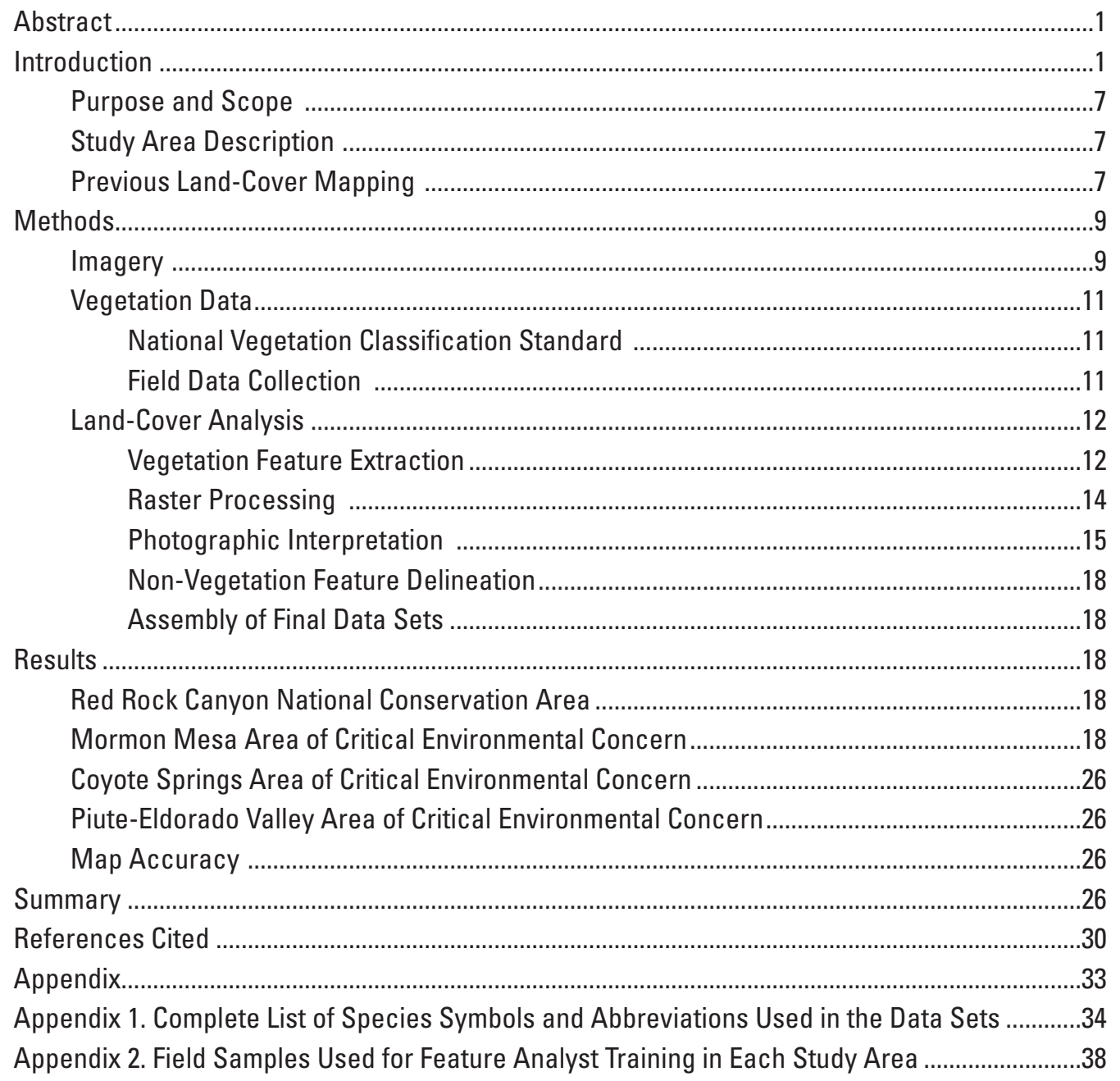




\section{Figures}

1. Map showing Clark County, Nevada, and the study areas

2. Map showing Red Rock Canyon National Conservation Area, and surrounding area

3. Map showing Coyote Springs Area of Critical Environmental Concern, and surrounding area

4. Map showing Piute-Eldorado Valley Area of Critical Environmental Concern, and surrounding area

5. Map showing Mormon Mesa Area of Critical Environmental Concern, and surrounding area

6. Map showing Western United States, including the Great Basin Physiographic Province and the major deserts of North America.

7. Map showing locations and dates of QuickBird imagery acquisition strips and digital orthophoto quarter-quadrangle tiles over Clark County, Nevada

8. A QuickBird multispectral digital orthophoto quarter-quadrangle showing the hierarchical learning process: $A$, a training polygon around an exemplar field sample; $B$, the results of initial learning; $C$, marking correct and incorrect areas in the "remove clutter" process; and $D$, results of hierarchical learning

9. Overview of the feature extraction process

10. Detail example showing resolution of areas of confusion: $A$, Areas of confusion shown in red and magenta; $B$, Areas in red were resolved by filtering with Euclidian distance filter, Nibble, used to fill in surrounding pixel values. Larger area in magenta was assigned a single pixel value from the confused values...

11. Diagram showing raster processing workflow

12. Map showing selected area of Red Rock Canyon National Conservation Area mapped by $A$, Southwest Regional Gap Program Ecological System and by $B$, National Vegetation Classification Standard macrogroup .

13. Map showing selected area of Red Rock Canyon National Conservation Area mapped by $A$, National Vegetation Classification Standard macrogroup and $B, N V C$ alliance 


\section{Tables}

1. The National Vegetation Classification Standard naming hierarchy and criteria.............9

2. Number of strips and dates of imagery in each study area ..........................................12

3. Summary of major reclassifications resulting from photo interpretation by study area

4. Number of unique classes and associated National Vegetation Classification Standard hierarchy categories by study area .

5. Map class code, map class, area, and alliance in the Red Rock Canyon National Conservation Area.

6. Map class code, map class, area, and alliance in the Mormon Mesa Area of Critical Environmental Concern.

7. Map class code, map class, area, and alliance in the Coyote Springs Area of Critical Environmental Concern.

8. Map class code, map class, area, and alliance in the Piute-Eldorado Valley Area of Critical Environmental Concern. 


\section{Conversion Factors}

\begin{tabular}{|c|c|c|}
\hline Multiply & By & To obtain \\
\hline \multicolumn{3}{|c|}{ Length } \\
\hline centimeter $(\mathrm{cm})$ & 0.3937 & inch (in.) \\
\hline millimeter (mm) & 0.03937 & inch (in.) \\
\hline meter (m) & 3.281 & foot $(\mathrm{ft})$ \\
\hline kilometer (km) & 0.6214 & mile (mi) \\
\hline kilometer (km) & 0.5400 & mile, nautical (nmi) \\
\hline meter $(\mathrm{m})$ & 1.094 & yard (yd) \\
\hline \multicolumn{3}{|c|}{ Area } \\
\hline square meter $\left(\mathrm{m}^{2}\right)$ & 0.0002471 & acre \\
\hline hectare (ha) & 2.471 & acre \\
\hline square hectometer $\left(\mathrm{hm}^{2}\right)$ & 2.471 & acre \\
\hline square kilometer $\left(\mathrm{km}^{2}\right)$ & 247.1 & acre \\
\hline square centimeter $\left(\mathrm{cm}^{2}\right)$ & 0.001076 & square foot $\left(\mathrm{ft}^{2}\right)$ \\
\hline square meter $\left(\mathrm{m}^{2}\right)$ & 10.76 & square foot $\left(\mathrm{ft}^{2}\right)$ \\
\hline square centimeter $\left(\mathrm{cm}^{2}\right)$ & 0.1550 & square inch $\left(\mathrm{ft}^{2}\right)$ \\
\hline square hectometer $\left(\mathrm{hm}^{2}\right)$ & 0.003861 & section (640 acres or 1 square mile) \\
\hline hectare (ha) & 0.003861 & square mile $\left(\mathrm{mi}^{2}\right)$ \\
\hline square kilometer $\left(\mathrm{km}^{2}\right)$ & 0.3861 & square mile $\left(\mathrm{mi}^{2}\right)$ \\
\hline
\end{tabular}

Vertical coordinate information is referenced to North American Vertical Datum of 1988 (NAVD 88).

Horizontal coordinate North American Datum of 1983 (NAD 83).

Elevation, as used in this report, refers to distance above the vertical datum. 


\section{Glossary}

This report uses geographic information system (GIS) and remote sensing terminology, including some terms specific to ArcGIS software. These definitions were modified from ESRI (2013).

\begin{tabular}{|c|c|}
\hline Term & Definition \\
\hline Image/imagery & $\begin{array}{l}\text { A representation or description of a scene, typically produced by an optical or } \\
\text { electronic device. Common examples include remotely sensed data (for example, } \\
\text { satellite data), scanned data, and photographs. }\end{array}$ \\
\hline Raster & $\begin{array}{l}\text { A GIS data set that defines space as an array of equally sized cells, called pixels, } \\
\text { arranged in rows and columns. Each pixel contains an attribute value and location } \\
\text { coordinates. }\end{array}$ \\
\hline Pixel & $\begin{array}{l}\text { The smallest unit of information in a raster, usually square. A pixel is represented } \\
\text { in a remotely sensed image as a cell in an array of data values. Often used } \\
\text { synonymously with cell. }\end{array}$ \\
\hline Vector & $\begin{array}{l}\text { A GIS data set that uses a coordinate-based data model to represent geographic } \\
\text { features as points, lines, or polygons. Types of vector data sets include shapefiles } \\
\text { and geodatabase feature classes. }\end{array}$ \\
\hline Shapefile & One type of vector data set. \\
\hline Attribute & $\begin{array}{l}\text { Nonspatial information about a geographic feature in a GIS. In raster data sets, the } \\
\text { information is associated with the pixel value. In vector data sets, the information } \\
\text { is usually stored in a table and linked to the feature by a unique identifier. }\end{array}$ \\
\hline
\end{tabular}

ESRI, 2013, GIS dictionary, accessed September 29, 2013, http://support.esri.com/en/knowledgebase/gisdictionary/browse. 


\section{Acknowledgments}

The authors express their appreciation to the Bureau of Land Management for assistance with property access for data collection. The authors acknowledge efforts of many professors and students of the College of Southern Nevada who helped David Charlet establish vegetation sample plots.

A special thanks to Angela Pitt who worked for the USGS after field mapping with David Charlet. 


\title{
Land-Cover Mapping of Red Rock Canyon National Conservation Area and Coyote Springs, Piute-Eldorado Valley, and Mormon Mesa Areas of Critical Environmental Concern, Clark County, Nevada
}

\author{
By J. LaRue Smith, Nancy A. Damar, David A. Charlet, and Craig L. Westenburg
}

\begin{abstract}
DigitalGlobe's QuickBird satellite high-resolution multispectral imagery was classified by using Visual Learning Systems' Feature Analyst feature extraction software to produce land-cover data sets for the Red Rock Canyon National Conservation Area and the Coyote Springs, Piute-Eldorado Valley, and Mormon Mesa Areas of Critical Environmental Concern in Clark County, Nevada. Over 1,000 vegetation field samples were collected at the stand level. The field samples were classified to the National Vegetation Classification Standard, Version 2 hierarchy at the alliance level and above. Feature extraction models were developed for vegetation on the basis of the spectral and spatial characteristics of selected field samples by using the Feature Analyst hierarchical learning process. Individual model results were merged to create one data set for the Red Rock Canyon National Conservation Area and one for each of the Areas of Critical Environmental Concern. Field sample points and photographs were used to validate and update the data set after model results were merged. Non-vegetation data layers, such as roads and disturbed areas, were delineated from the imagery and added to the final data sets. The resulting land-cover data sets are significantly more detailed than previously were available, both in resolution and in vegetation classes.
\end{abstract}

\section{Introduction}

The Bureau of Land Management (BLM) administers more than half of the approximately 2 million hectares of land in Clark County, Nevada (fig. 1). Federal lands are often designated for specific uses or protection, requiring management plans tailored to those designations. In 1990, the Red Rock Canyon National Conservation Area (NCA; fig.2) was designated as Nevada's first National Conservation Area to protect and preserve geological, archaeological, ecological, cultural, scenic, scientific, wildlife, riparian, wilderness, endangered species, and recreation resources. The Coyote Springs (fig. 3), Piute-Eldorado Valley (fig. 4), and Mormon Mesa (fig. 5) Areas of Critical Environmental Concern (ACEC) were designated to protect critical habitat for the desert tortoise (Gopherus agassizii).

Regional and national land-cover and vegetation data sets are available that include these areas. These data sets are based on mid-resolution (30-meter) satellite imagery and delineate generalized vegetation communities. The available resolution and level of vegetation detail are not sufficient to support local resource management in these areas.

In 2006, the U.S. Geological Survey (USGS), in cooperation with the BLM, began a 4-year study of the Red Rock Canyon NCA to produce a land-cover data set from DigitalGlobe's QuickBird high-resolution (2.4-meter) satellite imagery and field vegetation data. In 2010, the study was extended to include the Clark County portion of Mormon Mesa, and Coyote Springs and Piute-Eldorado Valley ACECs. Visual Learning Systems' feature extraction software, Feature Analyst, was used to classify the imagery on the basis of detailed field data (Visual Learning Systems, Inc., 2008). A minimum mapping unit of 0.1 hectares was used, or about one-quarter the size of previously available data. Vegetation data collection included more than 1,000 field samples that were used as possible training sites in the feature extraction process. Sampling protocol and naming conventions for the field data collection followed the National Vegetation Classification Standard, Version 2 (NVC; Federal Geographic Data Committee, 2008). The imagery and field data were used to map vegetation communities at the stand level, in which the dominant species in each canopy layer are identified. Nonvegetated data layers were also derived from the imagery. 


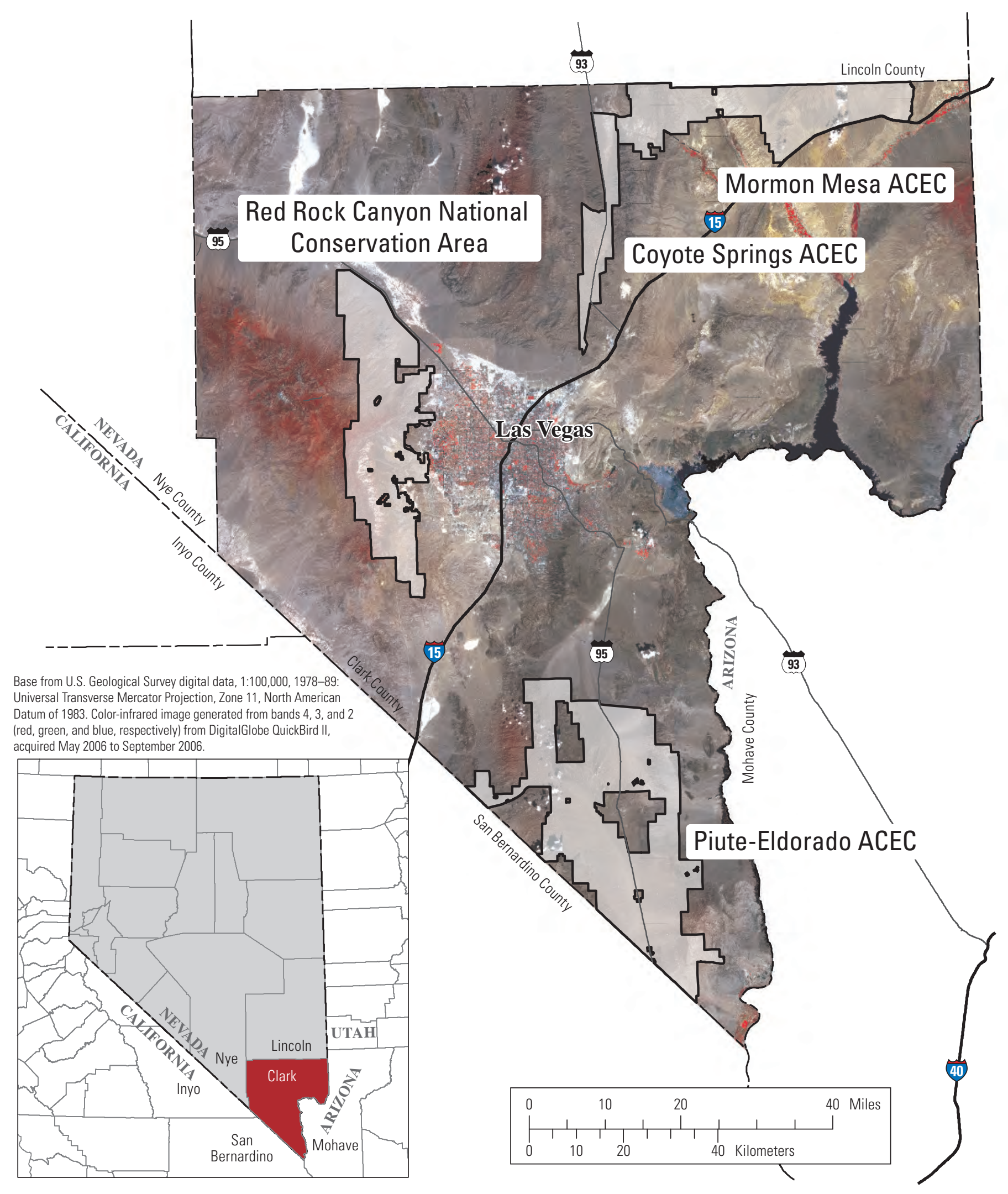

Figure 1. Clark County, Nevada, and the study areas. ACEC, Areas of Critical Concern. 


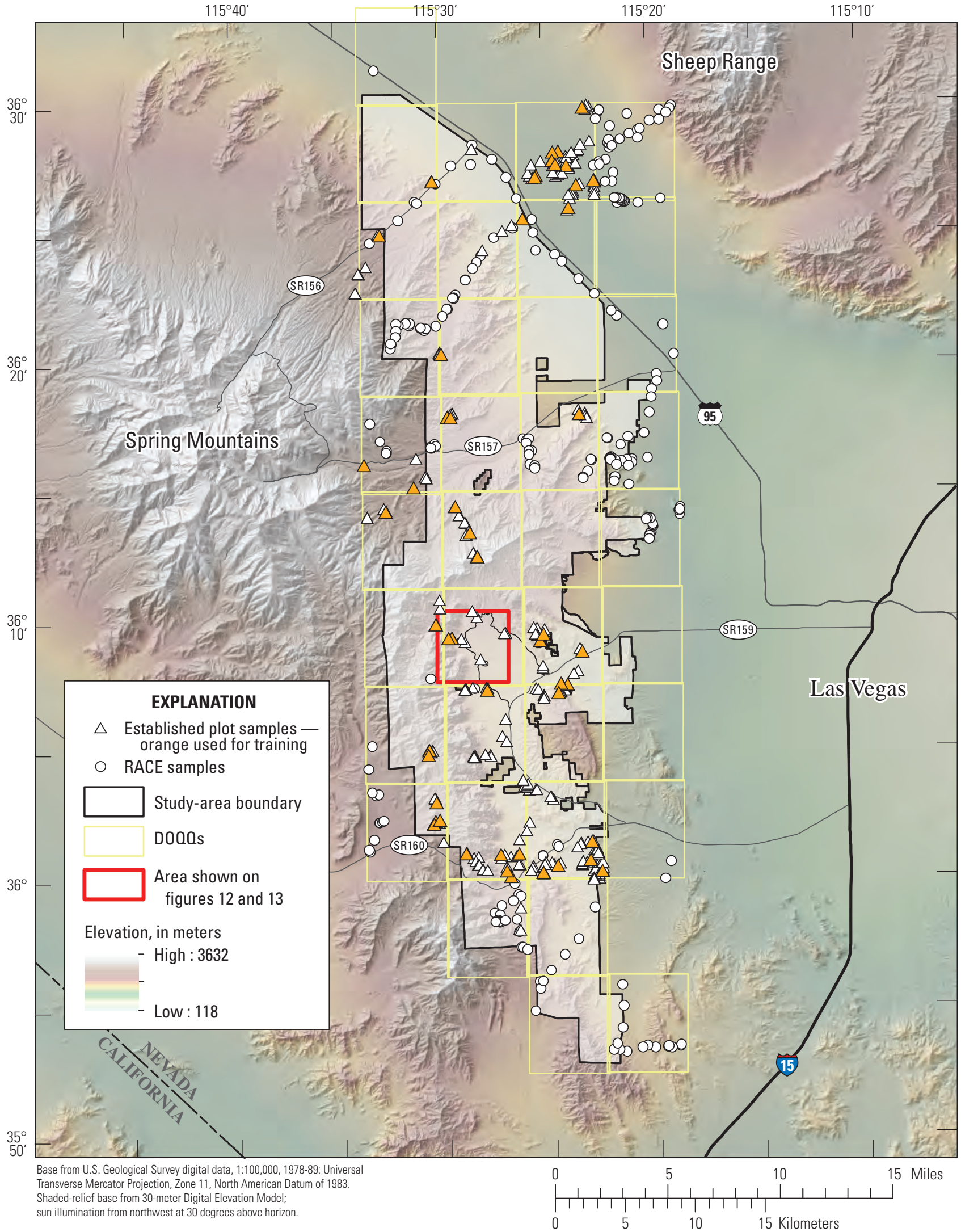

Figure 2. Red Rock Canyon National Conservation Area, and surrounding area. D000, digital orthophoto quarter-quadrangle; RACE, rapid assessment community ecology. 


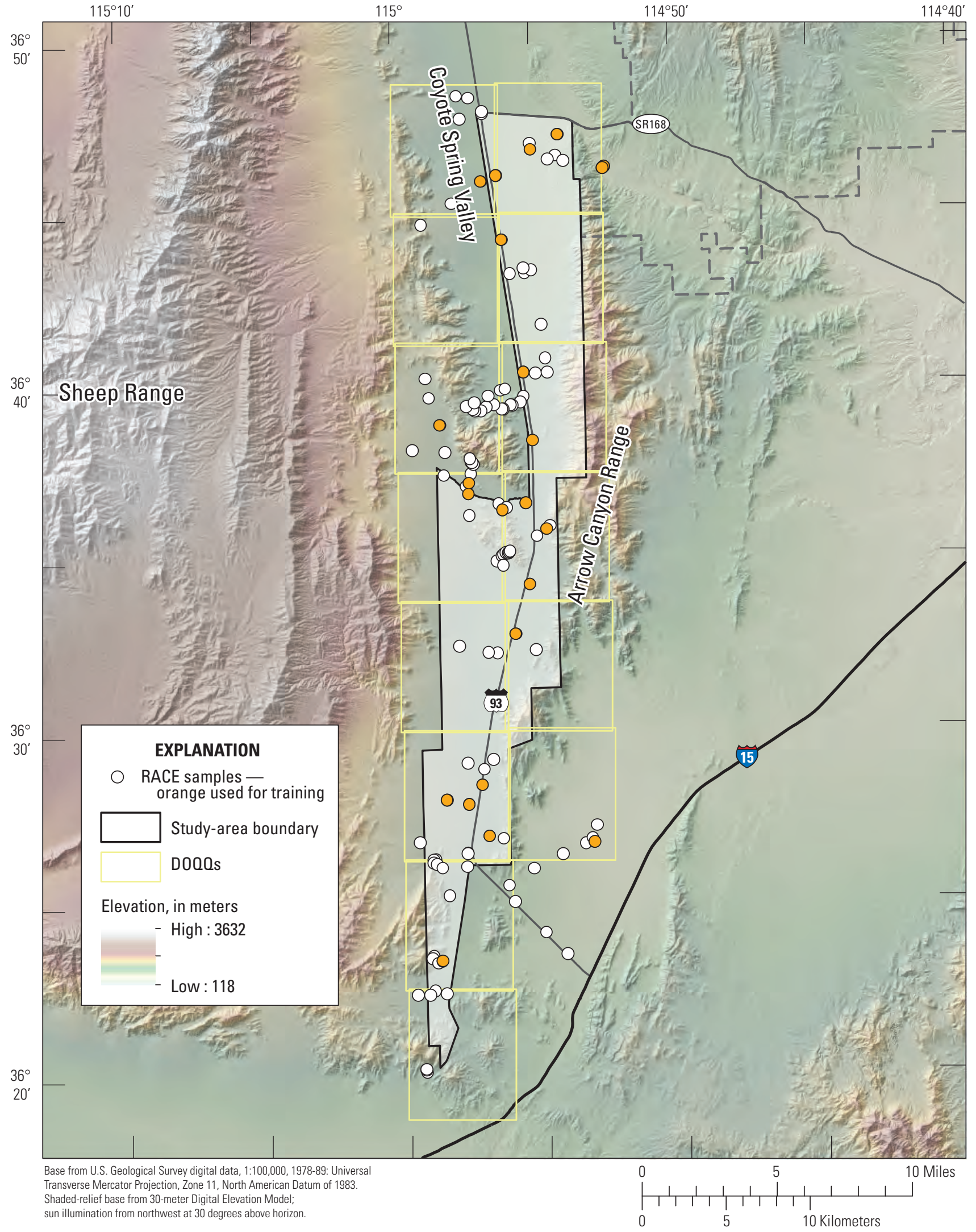

Figure 3. Coyote Springs Area of Critical Environmental Concern, and surrounding area. D000, digital orthophoto quarter-quadrangle; RACE, rapid assessment community ecology. 


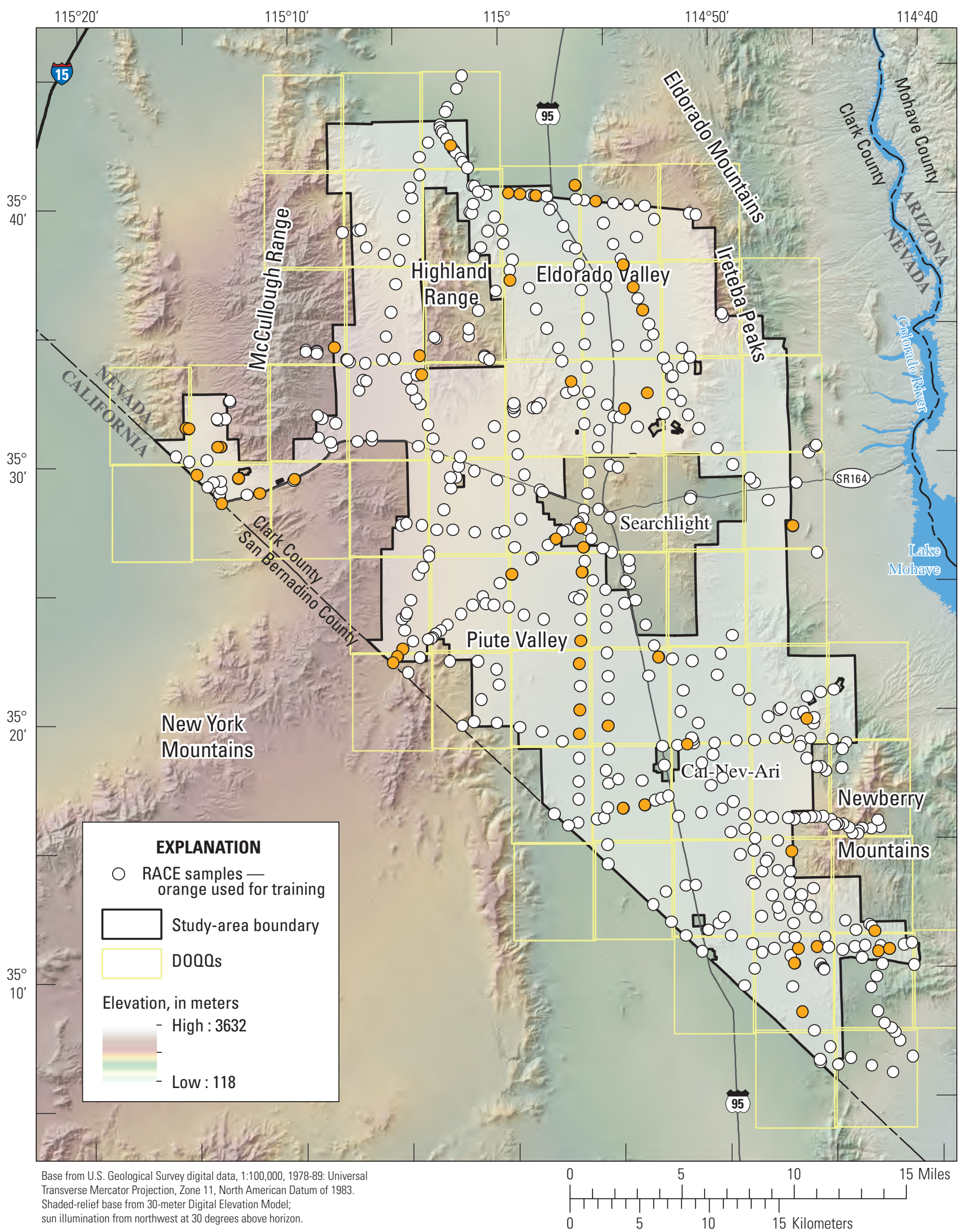

Figure 4. Piute-Eldorado Valley Area of Critical Environmental Concern, and surrounding area. D000, digital orthophoto quarterquadrangle; RACE, rapid assessment community ecology. 


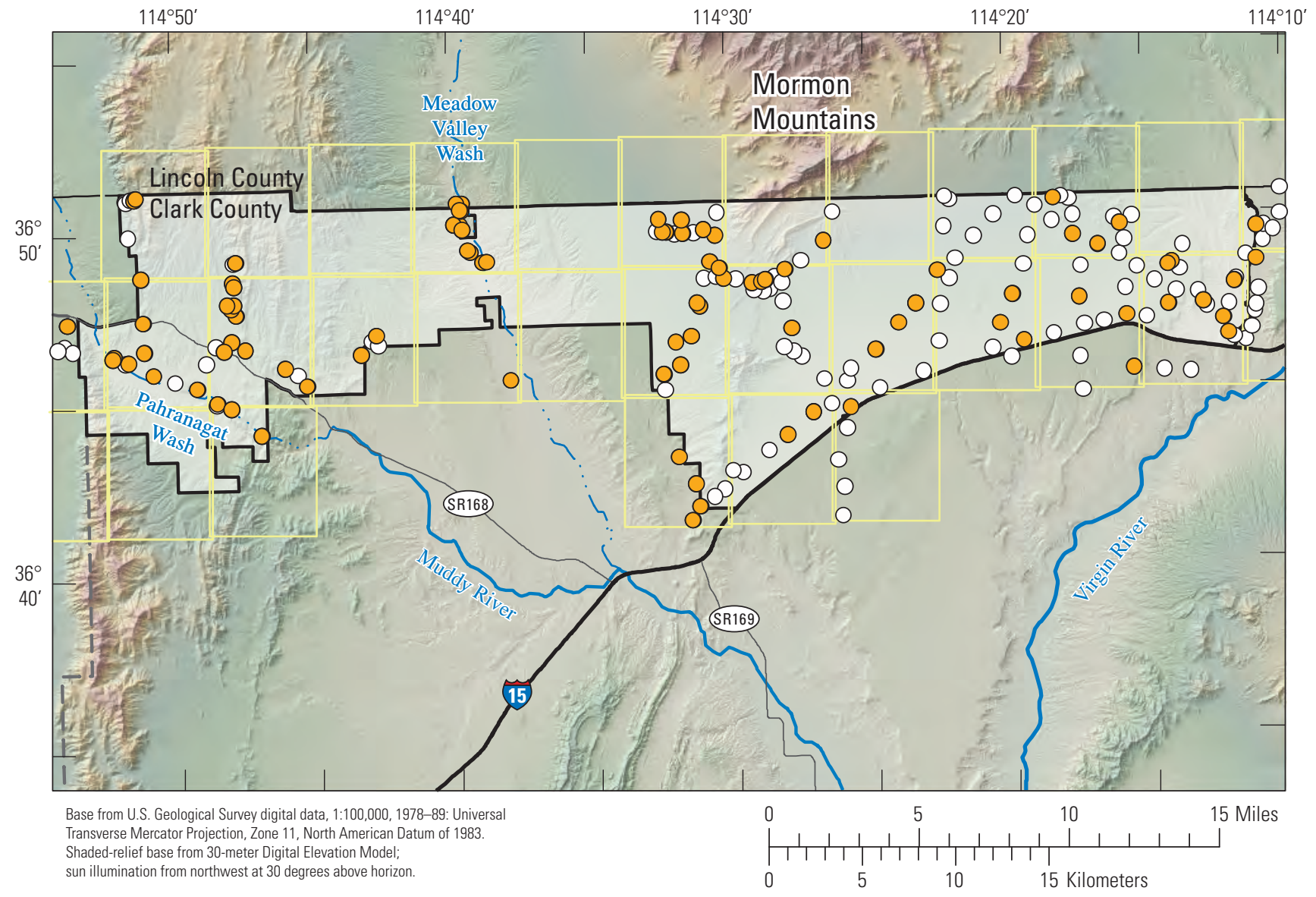

\begin{tabular}{|c|c|}
\hline \multicolumn{2}{|r|}{ EXPLANATION } \\
\hline \multirow[t]{3}{*}{0} & $\begin{array}{l}\text { RACE samples - } \\
\text { orange used for training }\end{array}$ \\
\hline & Study-area boundary \\
\hline & D000s \\
\hline \multicolumn{2}{|c|}{ Elevation, in meters } \\
\hline & - Low : 117.691 \\
\hline
\end{tabular}

Figure 5. Mormon Mesa Area of Critical Environmental Concern, and surrounding area. D000, digital orthophoto quarter-quadrangle; RACE, rapid assessment community ecology. 


\section{Purpose and Scope}

The purpose of this study was to produce detailed, highresolution land-cover data sets of the Red Rock Canyon NCA and the Coyote Springs, Piute-Eldorado Valley, and Mormon Mesa ACECs. This report documents the methods used in the land-cover mapping process. Field data collection techniques are briefly summarized. Full documentation of the data collection techniques and a database of the field samples are available in Charlet and others (2014). Land-cover data are presented as vector geographic information system (GIS) data sets with attributes for map class code attribute and a table of the associated NVC hierarchy from the alliance to the class level. Vegetation communities are summarized for each study area.

For the purpose of this report, the Red Rock Canyon NCA is referred to as the NCA and the Coyote Springs, Piute-Eldorado Valley, and Mormon Mesa ACECs jointly as the ACECs. All areas are referred to collectively as the study areas.

\section{Study Area Description}

Clark County is in the transition between the Mojave and Great Basin deserts, in the southern Great Basin region of the Basin and Range physiographic area (fig. 6; Shreve, 1942, and Fenneman and Johnson, 1946). The topographic relief of the region is responsible for strong elevation gradients evident in the vegetation communities present (Brussard and others, 1999). At the highest elevations, juniper, pinyon, and bristlecone pines are found. At mid-elevations, which characterize most of the study area, there are Joshua trees, Mojave yucca, creosote bush, often associated with white bursage, or black brush. Phreatophytes can be found at the lowest elevations, where depth to groundwater is shallow. In general, vegetation is typical of the semiarid desert southwest, sparse and shrubby (Longwell and others, 1965). Total annual precipitation ranges from 5 to 33 centimeters, with a mean of 12 centimeters per year (Daly and others, 2004). The majority of precipitation falls in the winter as rain; consequently, spring is the primary growing season. Most perennial species go at least partially dormant in the summer months, when temperatures can exceed $40^{\circ}$ Celsius (Smith and Nowak, 1990).

\section{Previous Land-Cover Mapping}

Most previous mapping efforts that include the study areas are at a national or regional scale, such as the National Land-Cover Database (NLCD; Homer and others, 2012) and the National Gap Analysis Programs (GAP; Maxwell and others, 2010). Because they cover large areas, they use midresolution satellite data and broad land-cover classes.
The NLCD is a Landsat-derived, 30-meter $(\mathrm{m})$ resolution, land-cover database for the United States. The minimum mapping unit is 0.4 hectares. There have been three major data releases: circa 1992, circa 2001, and circa 2006. The data releases are standardized so that changes in land cover over time can be assessed. The vegetation-related land-cover classes describe very general physiognomy, for example, Evergreen Forest or Shrub/Scrub. This level of detail can be equated to the upper levels of the NVC hierarchy (table 1).

The GAP National Land Cover Data is a national program with the mission of developing key datasets to assess biological diversity across the nation. Like NLCD, it is based on 30-meter resolution Landsat imagery and has a minimum mapping unit of 0.4 hectares. It combines land-cover data generated by many regional GAP programs, such as the Southwest ReGAP (SWReGAP) program that covers Arizona, Colorado, Nevada, New Mexico, and Utah (Prior-Magee and others, 2007). The SWReGAP data use NatureServe's Ecological Systems Classification (Comer and others, 2003). The BLM has correlated the Ecological Systems to the macrogroup level of the NVC hierarchy and uses these data as input for mid-scale management priorities (Bureau of Land Management, 2013).

Clark County, Nevada, further refined the SWReGAP data by using local data as part of its Multiple Species Habitat Conservation Plan (MSHCP). The purpose of MSHCP was to develop a county-wide, multiple species, ecosystem-based habitat conservation strategy and management plan for threatened, endangered, or locally sensitive species. The MSHCP Ecosystem Map for Clark County was produced in 2000 and was updated in 2011 (RECON Environmental, Inc., 2000; Heaton and others, 2011). Ecological zones and vegetation types are the primary bases of organization for habitat conservation planning. Field methods developed and data collected for the 2011 update of the MSHCP Ecosystem Map were also used in this study.

The BLM published an environmental assessment for the NCA in response to increased interest in oil and gas exploration in the late 1970s (Bureau of Land Management, 1980). This assessment includes maps and descriptions of geology, soil, hydrology, and other environmental features, including vegetation types. The vegetation map was compiled from an unpublished internal range inventory at a scale of 1 to 62,500 . The map included land-cover units of pinyon-juniper, Joshua tree, rabbitbrush, oak brush, blackbrush, manzanita, desert shrub, unique vegetation, and barren rock. This study is the only known local effort to map vegetation in any of the study areas previous to this report. 


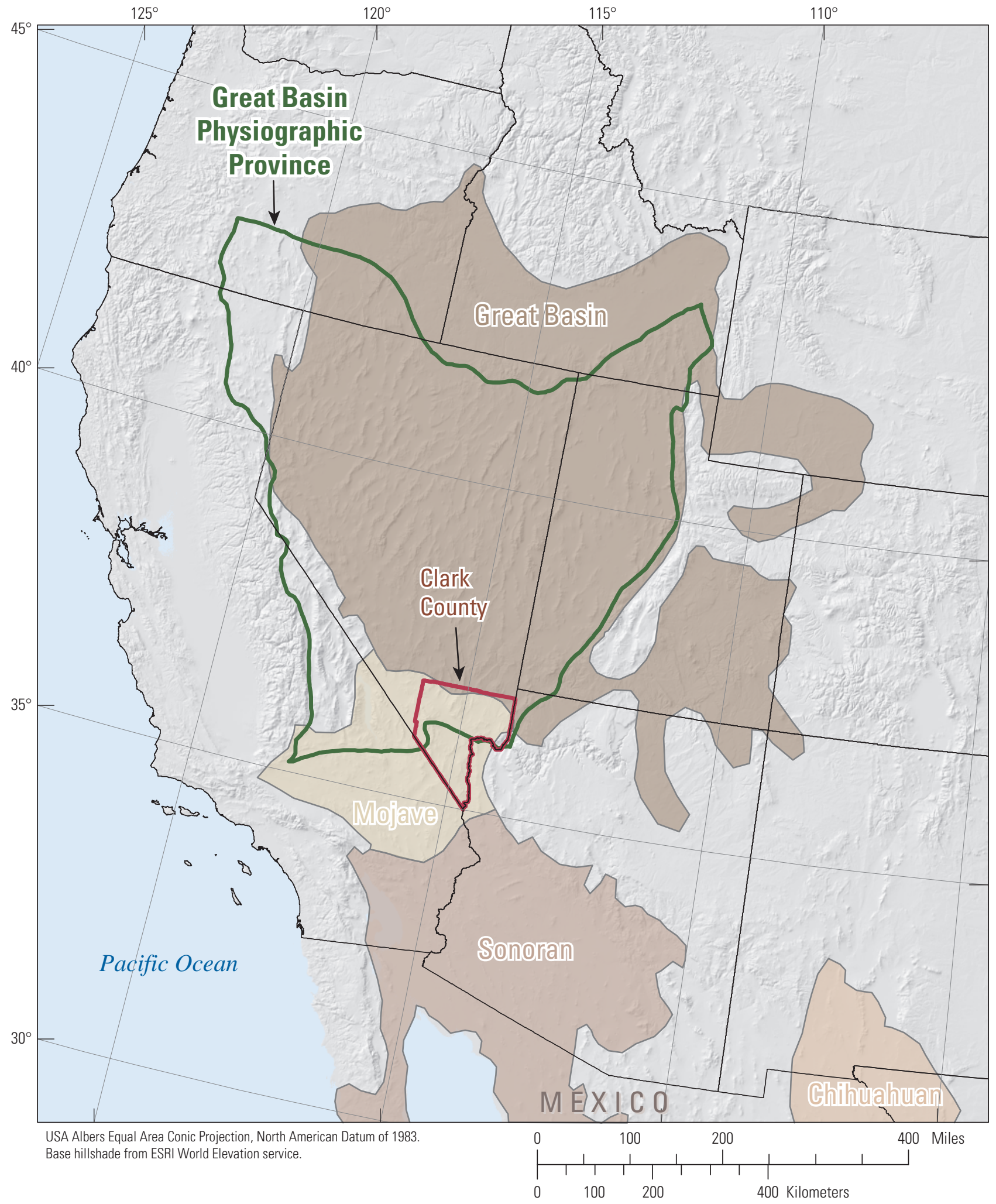

Figure 6. Western United States, including the Great Basin Physiographic Province (Fenneman and Johnson, 1946) and the major deserts of North America (Shreve, 1942). 
Table 1. The National Vegetation Classification Standard (NVC) naming hierarchy and criteria.

[Source: Federal Geographic Data Committee, 2008, National vegetation classification standard, version 2, FGDC-STD-005-2008: accessed December 6, 2012, http://www.fgdc.gov/standards/projects/FGDC-standards-projects/vegetation/NVCS_V2_FINAL_2008-02.pdf.]

\begin{tabular}{|c|c|}
\hline NVC Hierarchy Level & Criteria \\
\hline L1-Class & $\begin{array}{l}\text { Broad combinations of general dominant growth forms that are adapted to basic temperature (energy budget), } \\
\text { moisture, and/or substrate or aquatic conditions. }\end{array}$ \\
\hline L2-Subclass & $\begin{array}{l}\text { Combinations of general dominant and diagnostic growth forms that reflect global macroclimatic factors driven } \\
\text { primarily by latitude and continental position, or that reflect overriding substrate or aquatic conditions. }\end{array}$ \\
\hline L3-Formation & $\begin{array}{l}\text { Combinations of dominant and diagnostic growth forms that reflect global macroclimatic factors as modified by } \\
\text { altitude, seasonality of precipitation, substrates, and hydrologic conditions. }\end{array}$ \\
\hline \multicolumn{2}{|r|}{ Middle: Both floristics and physiognomy play a significant role. } \\
\hline L4-Division & $\begin{array}{l}\text { Combinations of dominant and diagnostic growth forms and a broad set of diagnostic plant taxa that reflect } \\
\text { biogeographic differences in composition and continental differences in mesoclimate, geology, substrates, } \\
\text { hydrology, and disturbance regimes. }\end{array}$ \\
\hline L5-Macrogroup & $\begin{array}{l}\text { Combinations of moderate sets of diagnostic plant species and diagnostic growth forms that reflect biogeographic } \\
\text { differences in composition and subcontinental to regional differences in mesoclimate, geology, substrates, } \\
\text { hydrology, and disturbance regimes. }\end{array}$ \\
\hline \multicolumn{2}{|r|}{ Lower: Floristics plays a predominant role. } \\
\hline L7-Alliance & $\begin{array}{l}\text { Diagnostic species, including some from the dominant growth form or layer, and moderately similar composition that } \\
\text { reflect regional to subregional climate substrates, hydrology, moisture/nutrient factors, and disturbance regimes. }\end{array}$ \\
\hline L8-Association & $\begin{array}{l}\text { Diagnostic species, usually from multiple growth forms or layers, and more narrowly similar composition that reflect } \\
\text { topo-edaphic climate, substrates, hydrology, and disturbance regimes. }\end{array}$ \\
\hline
\end{tabular}

\section{Methods}

\section{Imagery}

DigitalGlobe’s QuickBird satellite acquired highresolution imagery covering all of Clark County between May and September of 2006. The imagery was acquired in strips oriented from north to south that correspond to the path flown over the Earth by the satellite (fig. 7). The QuickBird satellite is equipped with two sensors (multispectral and panchromatic) to measure reflected solar radiation, also called spectral reflectance. The multispectral sensor records the reflectance as four discreet bands in the blue $(0.45-0.52$ micrometers, or $\mu \mathrm{m})$, green $(0.52-0.60 \mu \mathrm{m})$, red $(0.63-0.69 \mu \mathrm{m})$, and near infrared $(0.76-0.89 \mu \mathrm{m})$ regions of the electromagnetic spectrum with a spatial resolution of 2.4 meters. The panchromatic sensor records a single band from the visible to near infrared $(0.445-0.90 \mu \mathrm{m})$ region of the electromagnetic spectrum with a spatial resolution of $0.6 \mathrm{~m}$. The imagery was delivered as two sets of orthorectified tiles organized by acquisition strip, one set each for the multispectral and panchromatic data. Tiles are referenced to USGS 1 to 24,000-scale map quadrangles. Each tile represents a quarter of a quadrangle and is referred to as a digital orthophoto quarter-quadrangle (DOQQ). A third, pan-sharpened, data set was created that combined the 0.6-meter panchromatic tiles with the 2.4-meter multispectral tiles by using a wavelet resolution merge (ERDAS, Inc., 2010). The pan-sharpened data set was used to delineate nonvegetation features and to aid in map validation.

The individual multispectral DOQQs that cover each study area were used as input for the feature extraction process (figs. 2-5). The feature extraction process relies on the assumption that a feature on the ground in one place will have the same spectral reflectance as that same feature on the ground in a different place. Many variables can interfere with this assumption, often relating to the temporal aspect of the imagery. For example, imagery collected on different days will be affected differently by varying atmospheric conditions on each day. The multispectral DOQQs covering the NCA were acquired on two dates: June 10 and 23, 2006. These DOQQs were atmospherically corrected using the ERDAS IMAGINE software plugin ATCOR (for ATmospheric CORrection; Geosystems, 2013). ATCOR uses information about the satellite sensors, atmospheric conditions at the time of acquisition, and the altitude of the land surface to correct for the effects of the atmosphere on the spectral reflectance values measured by the satellite sensor. Ground spectral reflectance from plants and soils in the NCA was measured with a field spectrometer from July 11 to 17,2006 , and was used to aid the atmospheric corrections. 


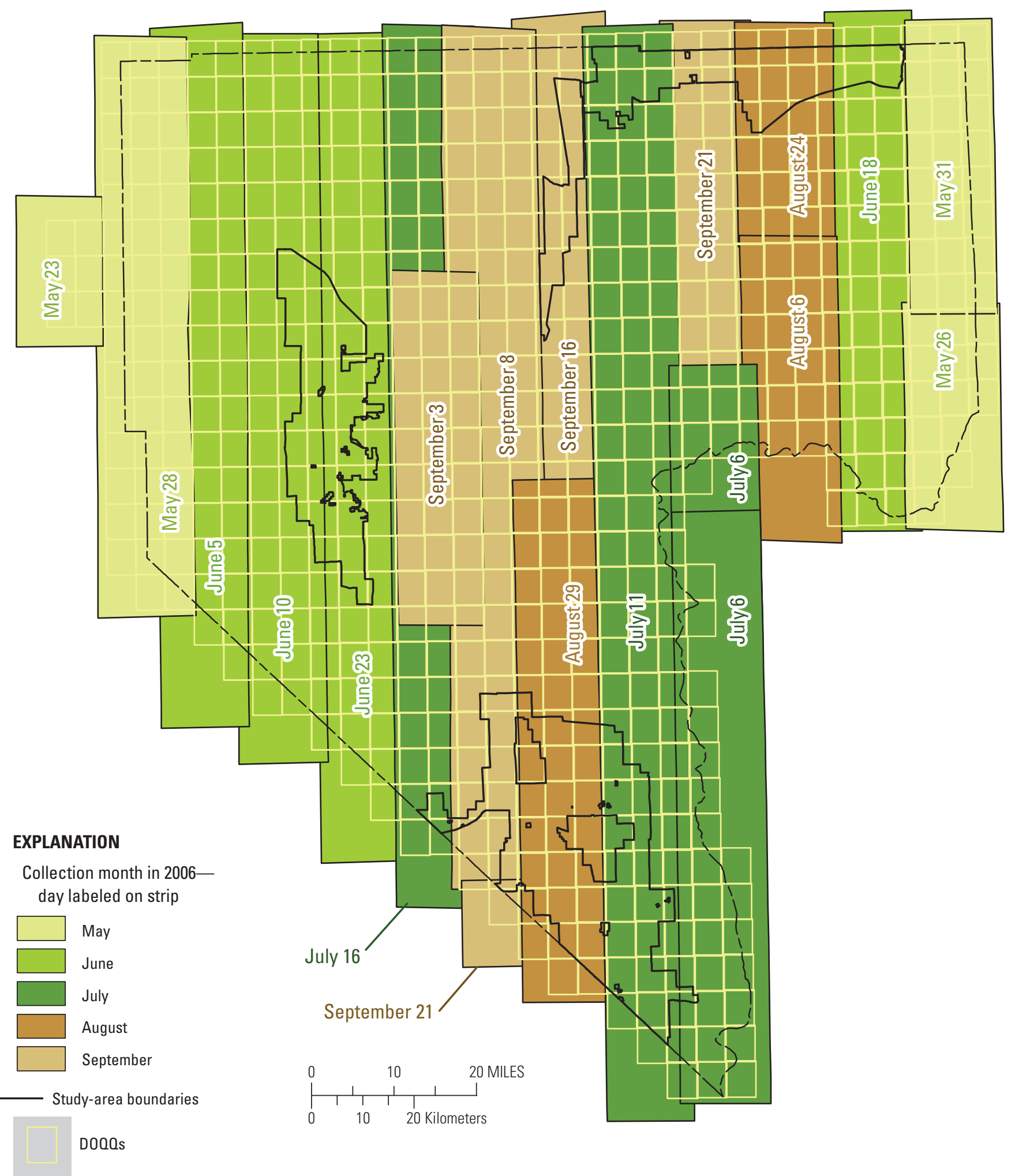

Figure 7. Locations and dates of QuickBird imagery acquisition strips and digital orthophoto quarter-quadrangle (D000) tiles over Clark County, Nevada. 
The DOQQs covering the ACECs were not atmospherically corrected. When the study was extended in 2010, it was too late to collect additional field spectrometer data in the ACECs to bolster corrections made there. More importantly, the broad range of acquisition dates of the strips covering the ACECs meant that ground conditions, and therefore spectral reflectance values, likely were not comparable across all strips as a result of variance in the growing season. To account for the variable ground conditions across the range of dates, DOQQs from some strips were modeled separately during the feature extraction process. Table 2 shows the dates of the strips for each study area and the modeling required.

\section{Vegetation Data}

\section{National Vegetation Classification Standard}

The National Vegetation Classification Standard, Version 2 (NVC), was developed by the U.S. Federal Geographic Data Committee (FGDC) to support a consistent naming hierarchy and sampling protocol for vegetation data collected at local, regional, and national levels. The naming hierarchy consists of eight levels. The upper levels are based on physiognomy and macroclimate. The levels become progressively more defined by floristics (table 1). Vegetation data were collected in the field at a level that allowed the samples to be worked through the NVC hierarchy at the alliance level and above (Charlet and others, 2014).

\section{Field Data Collection}

Vegetation data were collected in the field to identify training areas for the feature extraction process. Sample sites were selected to ensure that the extent of each site represented a homogenous stand and so that as many stands as possible could be sampled. Data were collected by a team of botanists in two formats: established plot samples and Rapid Assessment Community Ecology (RACE; Charlet and others, 2014) samples. Established plot samples generally followed the NVC protocol for identification plots; while RACE samples meet the NVC standards for occurrence plots. Identification plots have a more rigorous data collection protocol so that the data can be assessed with probability statistics and then used to confirm the existence of a community. Occurrence plots document one location of a previously confirmed community. Established plot samples were collected in the NCA; RACE samples were collected in the ACECs. The term "field sample" can refer to plot or RACE samples in this report.

The typical established plot sample was $20 \mathrm{~m}$ by $20 \mathrm{~m}$ square. In some cases, small or narrow vegetation stands did not conform to the square plot. In these cases, a rectilinear plot was designed so that the entire plot would represent the vegetation to be sampled, rather than crossing a boundary and including an adjacent, dissimilar vegetation stand that happened to be inside the square. In this way, linear vegetation features, such as along stream channels, could be sampled regardless of orientation or width. The southeast corner was the base of the plot, and its location was identified with a Global Positioning System (GPS) receiver and marked with rebar and tape. Points were established $20 \mathrm{~m}$ away in the true north and west directions.

The RACE sampling method was developed for the MSHCP to provide faster data collection and a greater redundancy of sampling (Charlet and others, 2014). This method was developed after sampling in the NCA, but before sampling began in the ACECs. Instead of marking a plot a few hundred square meters in size, the researcher used a GPS receiver to select a point and then traversed an area around the point within a $100 \mathrm{~m}$ radius. The point was the center of a circle with a set of observations that defined the stand present there. As with plots, some RACE sample sites were smaller than the default $100 \mathrm{~m}$ radius in order to sample stands that were not $100 \mathrm{~m}$ in all directions from the waypoint.

Three types of data were recorded for each field sample: (1) vegetation, (2) physical, and (3) photographic. Vegetation data for established plot samples include a visual estimate of percentage of cover for every species present. Vegetation data for RACE samples include a visual estimate of percentage of cover for any species that appears to have at least 5 percent cover and a list of all other species encountered. Physical data for all samples include coordinates taken with a GPS receiver and estimates of slope and aspect. Photographs capture multiple views of the stand, the ground cover present, and the surrounding landscape.

All samples were assigned a stand name based on the vegetation data collected at the site. The stand name defines the sample by the dominant species in each canopy layer in the sampled stand. A dominant species is any species with at least 5 percent cover in the canopy layer. The species names are placed in order from left to right, corresponding to top to bottom layers in the canopy structure of the stand, and are abbreviated with a four- or five-letter symbol consisting of the first two letters of the genus, followed by the first two letters of the species epithet. A fifth letter is sometimes placed at the end, when necessary, to indicate a specific taxon (subspecies or variety). This symbol naming convention is a simplified version of the taxonomy and nomenclature of the U.S. Department of Agriculture's PLANTS database (U.S. Department of Agriculture, 2013). The USDA symbols are more complex to account for any repetition of four-letter codes in a nationwide database. See appendix 1 for a complete list of symbols used in the report and data sets.

More than 1,000 established plot and RACE samples were collected in or near (falling within the DOQQs used for analysis) the study areas (figs. 2-5). Complete details about data collection methods and a database of all samples are available in Charlet and others (2014). 
Table 2. Number of strips and dates of imagery in each study area.

[Abbreviations ACEC, Area of Critical Environmental Concern; DOQQ, digital orthophoto quarter-quadrangle; NCA, National Conservation Area]

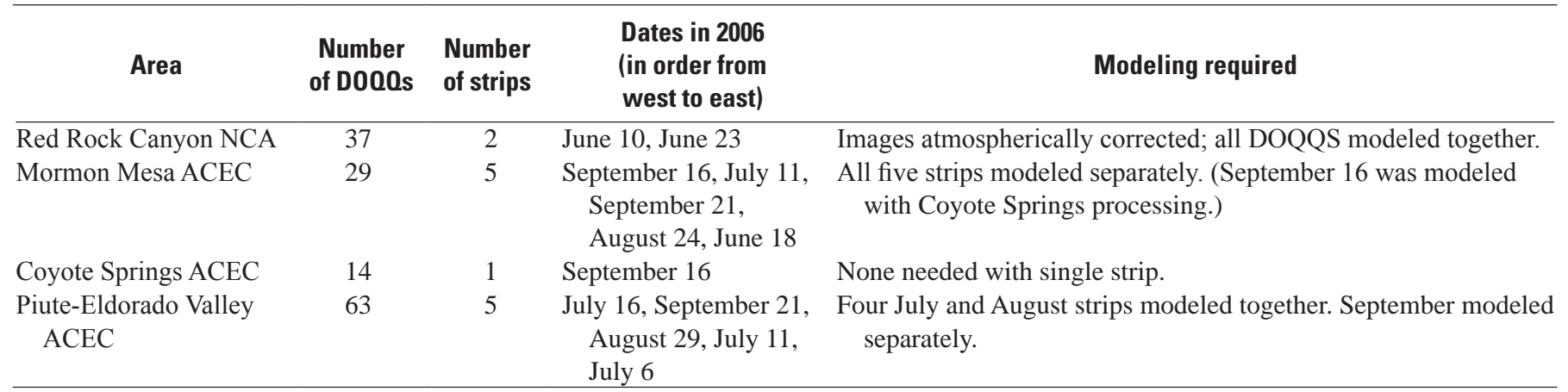

\section{Land-Cover Analysis}

The first step in the land-cover analysis was feature extraction by using Feature Analyst (FA) software. Feature extraction is a type of image classification in which pixels in an image that represent a particular feature are identified (that is, extracted). In this case, the features extracted were stands of vegetation, as defined by exemplary vegetation field samples. The samples were input into FA independently of each other and resulted in dozens of outputs per study area. Because they were produced independently, the outputs had overlaps with each other and gaps where no pixels were extracted. The outputs were combined into one data set per study area with no overlaps or gaps by using raster processing tools in ArcGIS. The combination data sets were evaluated and improved, if possible, by using all available field samples and other ancillary data during the photo interpretation phase. Lastly, non-vegetation units, such as roads, disturbed areas, and clouds, were produced separately and added to the final data sets.

\section{Vegetation Feature Extraction}

FA uses a hierarchical learning process to analyze the spectral reflectance values of input pixels and the spatial distribution of those pixels in the context of an exemplar input, or training area. The result of the hierarchical learning process is an automated feature extraction (AFE) model, which can be used to extract the target feature from multiple images.

Individual field samples were used to create the input training areas for the AFE models. A training area was created on a single DOQQ by delineating a polygon around or very near a field sample. An effort was made to choose an area that appeared to be spectrally homogenous. Along with the input training area, the analyst specified the minimum mapping unit of 0.1 hectares. FA honors this setting throughout the feature extraction process. The pixels of the DOQQ that fall within the polygon are analyzed spectrally and spatially by FA to create an AFE model. In the first step of the hierarchical learning process, FA uses the AFE model to identify the features (that is, pixels) in the DOQQ that fit the model. From this initial set of returned features, the analyst can choose from two methods to provide feedback on the returned features. In the "remove clutter" process, the analyst marks correct and incorrect features. In the "add missing" process, the analyst delineates new polygons around additional features that were missed. With either method, FA uses the feedback to improve the AFE model and return a new set of features (fig. 8). This feedback loop is repeated until the returned set of features is determined to adequately represent the training area. This determination is made by the analyst upon visual evaluation of the results in the context of nearby field samples and knowledge of the area.

The developed AFE model is then run for all of the DOQQs that cover a study area (or part of a study area, depending on the dates of the strips that contain the DOQQs, as discussed in the "Imagery" section) as a batch process. The batch process returns one feature set for every DOQQ as a set of polygon shapefiles. The set of shapefiles for a single AFE model is merged into a single shapefile and edited to clean up edge effects or other artifacts from the merging process. The shapefile is assigned a unique number and labeled with the stand name of the field sample used to produce it. The shapefile is then converted to a raster with a unique number as the pixel value (fig. 9). The pixel size of the raster is $2.4 \mathrm{~m}$ (same as the original multispectral data set) with the pixel boundaries equal to the envelope of the input DOQQs. The feature extraction process was repeated for many field samples in each study area. Appendix 2 lists the field samples used for each study area.

The AFE models were also developed without a field sample as the basis for the training area. This method was most often used when it was prohibitive to collect data in the area, but there was strong knowledge of the area. For example, the sandstone cliffs in the NCA and the rugged limestone bedrock in Mormon Mesa ACEC were easily identified from the multispectral imagery and training areas could be directly digitized. This method was also used to "reverse engineer" feature extraction in unclassified portions of a study area. In this case, a training site would be digitized in an unclassified portion of the study area, and an AFE model developed from it. If the shapefiles returned from the batch process overlapped a field sample or previously classified area, the known stand name was assigned to the output. 
$\boldsymbol{A}$

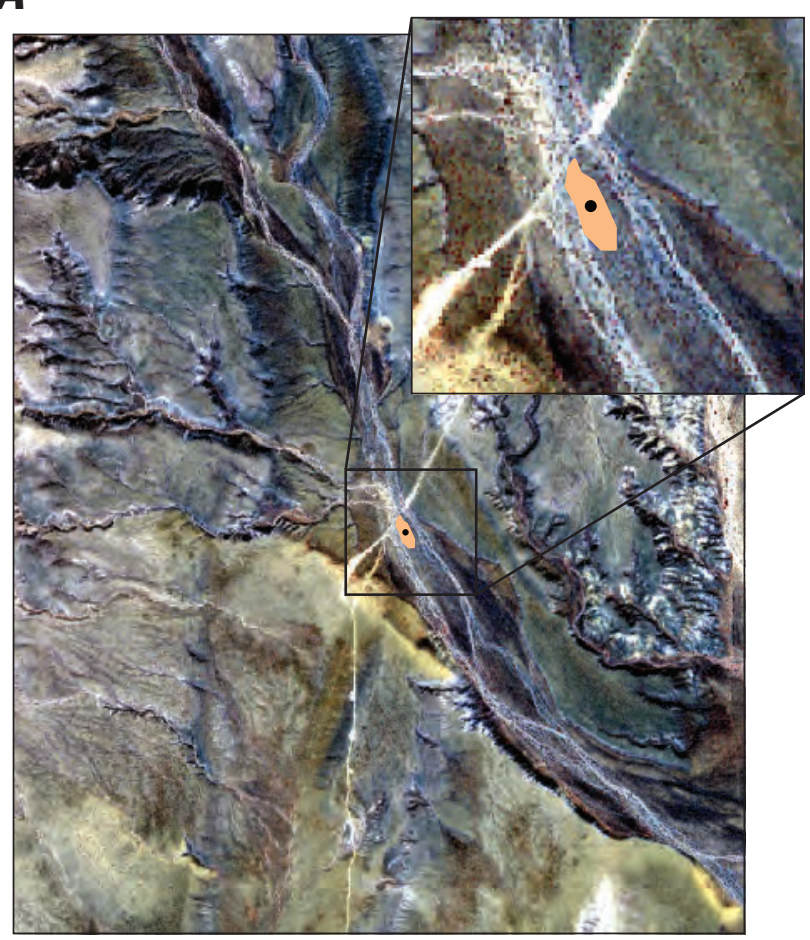

C

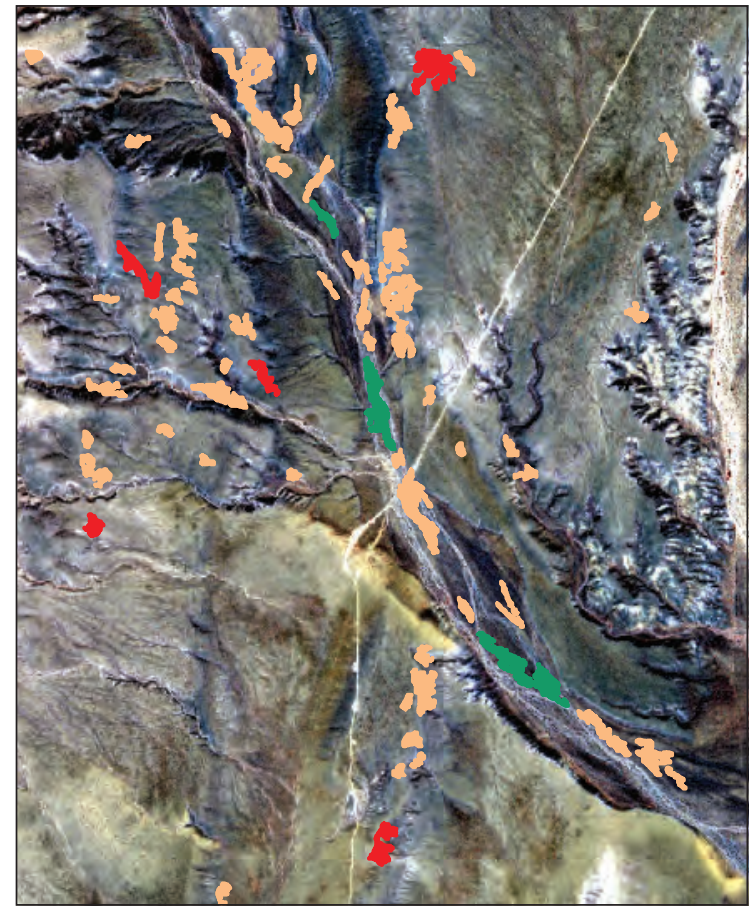

$\boldsymbol{B}$

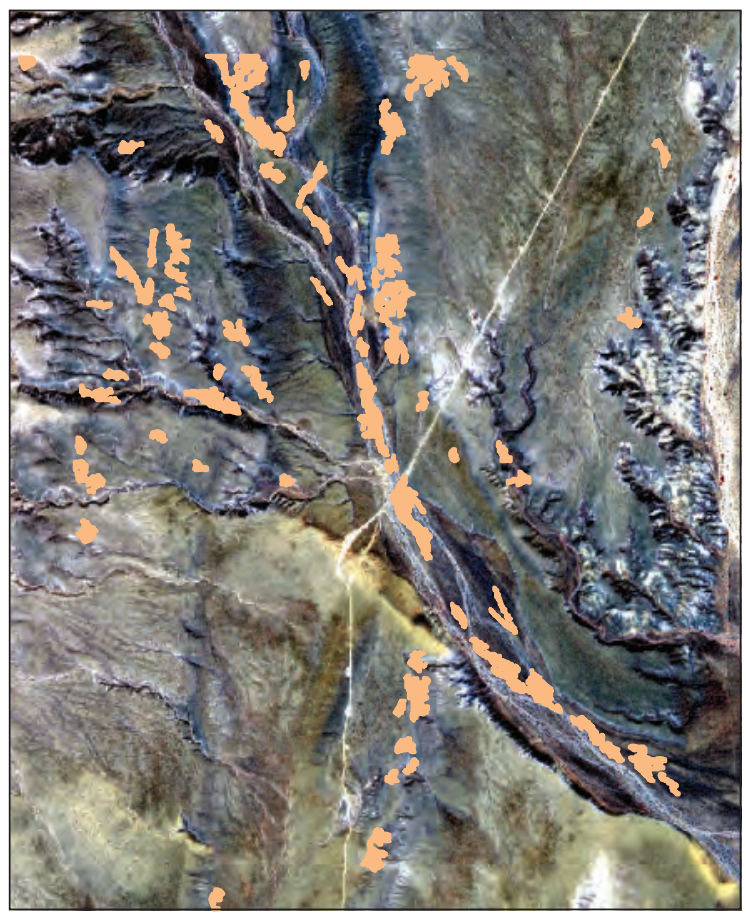

D

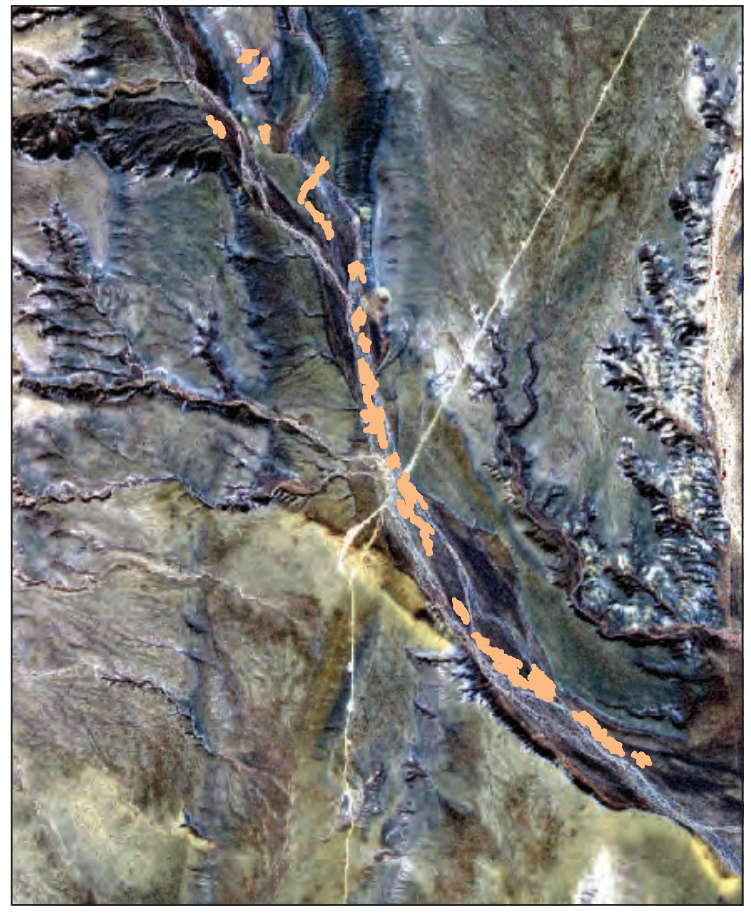

Figure 8. A QuickBird multispectral digital orthophoto quarter-quadrangle showing the hierarchical learning process: $A$, a training polygon around an exemplar field sample; $B$, the results of initial learning (beige); $C$, marking correct (green) and incorrect (red) areas in the "remove clutter" process; and $D$, results of hierarchical learning. 


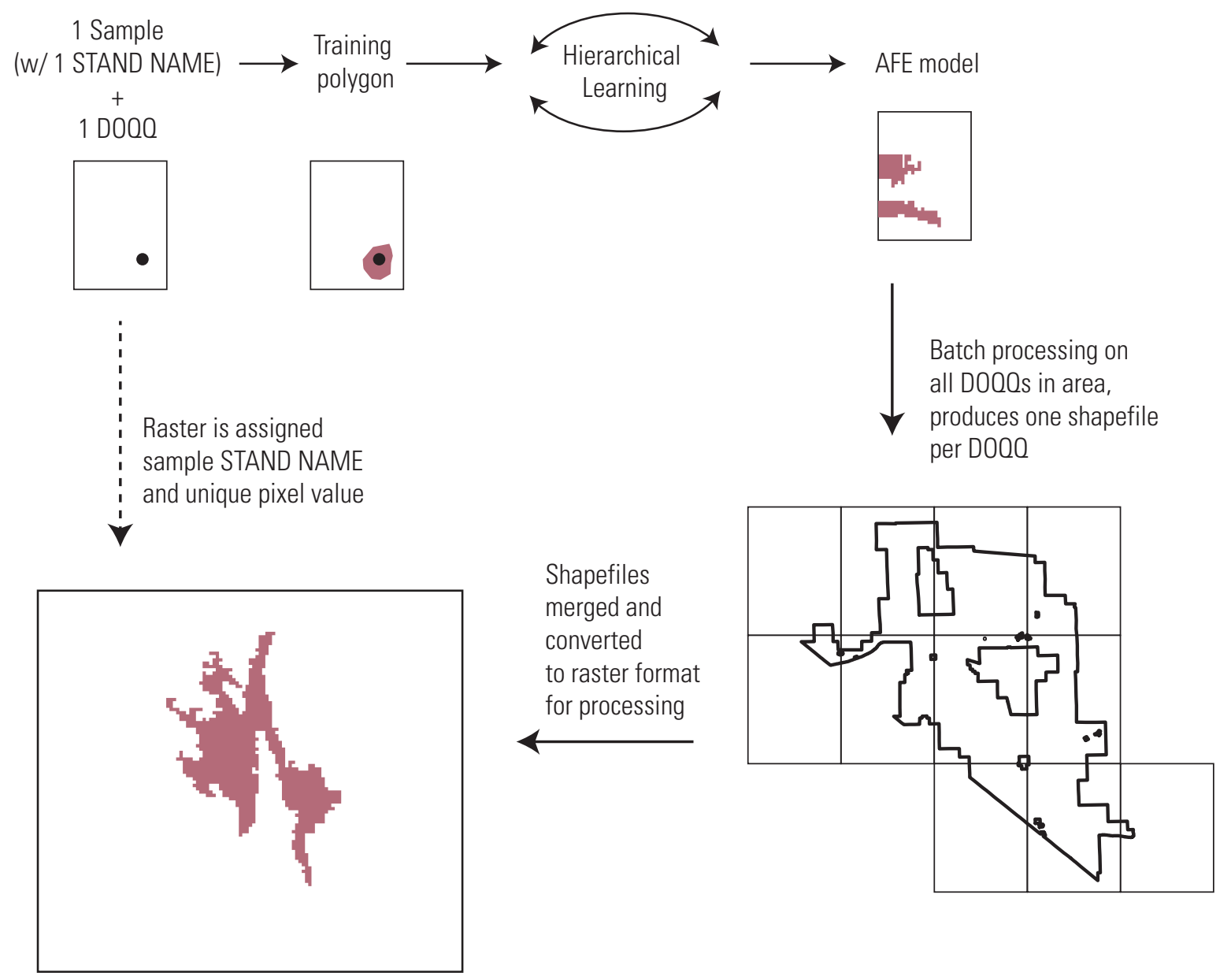

Figure 9. Overview of the feature extraction process. AFE, automated feature extraction; D000, digital orthophoto quarter-quadrangle.

\section{Raster Processing}

Raster processing uses ArcGIS tools to combine the individual rasters from the AFE models into a single data set. Between 20 and 100 AFE models were developed for each study area. Because AFE models were developed independently of each other, there was overlap between some rasters. These overlaps, called areas of confusion, resulted when FA identified a pixel with more than one AFE model. Areas of confusion occurred most often with stand names that had the same dominant species in the top canopy layer, but varying understories or soil conditions.

Areas of confusion were addressed by incrementally combining groups of rasters and resolving the confusion among them. First, rasters with the same or similar stand names were combined using the ArcGIS Combine tool (ESRI, 2011). Areas of confusion that were small relative to the mapped area were filtered with the ArcGIS Euclidian distance filter, Nibble (ESRI, 2011). Nibble assigns the pixel value of a pixel's nearest neighbor as measured by Euclidean distance. Larger areas of confusion were evaluated with nearby field samples and assigned one of the pixel values from the confused area (fig. 10).

The resulting rasters, which now contain pixel values from multiple stand names, were then evaluated relative to each other and assigned a confidence level. The confidence order was determined by an examination of the field samples and the analyst's knowledge of the vegetation. In general, a higher confidence was placed on rasters representing unique, infrequently observed stands, such as meadows, marshland, or riparian areas. These stands tend to occupy small areas and have distinct boundaries. Lower confidence was assigned to more frequently observed communities that tend to have broad transitional boundaries, such as shrublands. The rasters were then merged by confidence order, such that pixel values from rasters with high confidence were retained, while pixel values from rasters with low confidence were only retained where 


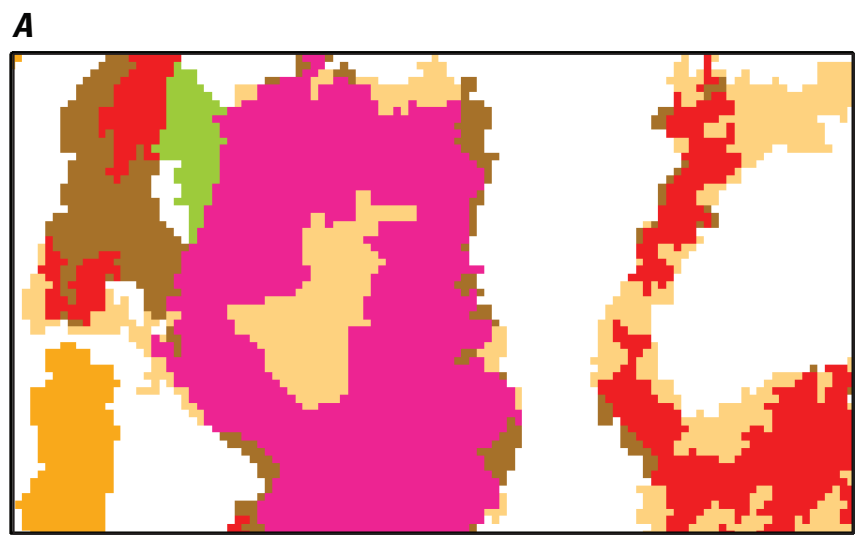

B

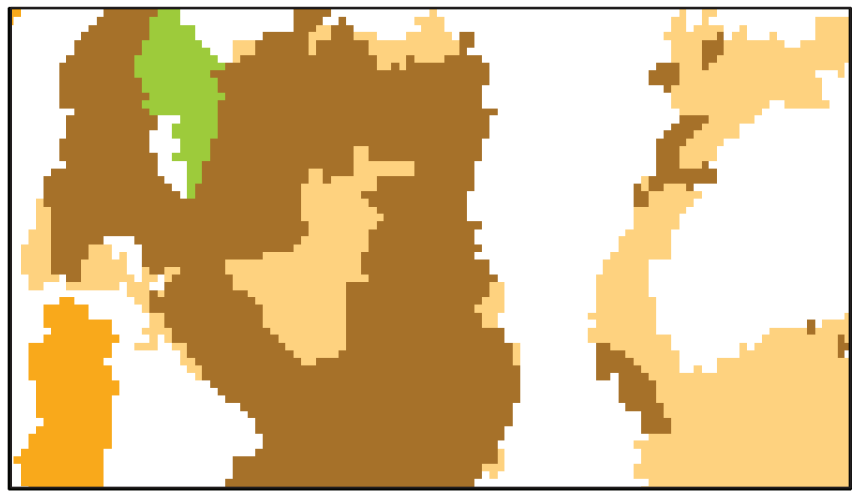

Figure 10. Detail example showing resolution of areas of confusion: $A$, Areas of confusion shown in red and magenta; $B$, Areas in red were resolved by filtering with Euclidian distance filter, Nibble, used to fill in surrounding pixel values. Larger area in magenta was assigned a single pixel value from the confused values.

there were no pixel values from higher confidence rasters (fig. 11). After this merge, one raster with many pixel values remained for each study area. It was examined for pixels with no assigned value, which were pixels that were not classified by any AFE model. Nibble was used to filter out areas smaller than the minimum mapping unit ( 0.1 hectare or 176 pixels), and the rest of the unclassified pixels were assigned a unique value and labeled as unclassified.

\section{Photographic Interpretation}

The final raster for each study area was evaluated through photographic interpretation. The pixels associated with each stand name were examined individually. The stand name was either confirmed as a final map class or changed as needed to better characterize what was known or believed to be correct on the ground.

The general procedure was to review on-screen the pixels associated with each stand name in the context of all field samples and photographs, as well as ancillary data such as topographic maps and digital elevation data. If needed to improve the map, pixels were reclassified to another existing or new stand name. For example, Quercus gambelii (QUGA) is unlikely to grow at low elevations. It was determined from field samples and pictures that Salix lasiolepis (SALA) was being misclassified as QUGA in the lower elevations of RRCNCA. The reclassification was made by outlining a general polygon to identify the area of incorrect classification. Any pixels within the polygon that had a stand name that contained QUGA were given a new stand name in which SALA replaced QUGA. The new stand names were then confirmed as a final map class. In this way, map classes were introduced that do not necessarily have corresponding field samples of the same name.

In some cases, all pixels of a stand name were assigned a different final map class. For example, some pixels had a stand name that includes Juniperus osteosperma (JUOS) and Pinus monophylla (PIMO) in the tree canopy layer, Purshia stansburiana (PUST) in the shrub canopy layer, and Artemisia nova (ARNO) in the grass canopy layer, abbreviated as JUOS-PIMO/PUST/ARNO. After reviewing the pixels, other JUOS-PIMO samples with understories other than PUST or ARNO plotted on the JUOS-PIMO/PUST/ARNO pixels. The stand name was generalized, and the pixels were assigned a final map class of JUOS-PIMO. See table 3 for a summary of changes made in each study area during photo interpretation. 
1 - Feature extraction results in many rasters, each with one unique pixel value.

2 - Rasters are grouped, and confusion is resolved; see figure 10 . Fewer rasters remain with multiple pixel values in each raster. Confidence is assigned.
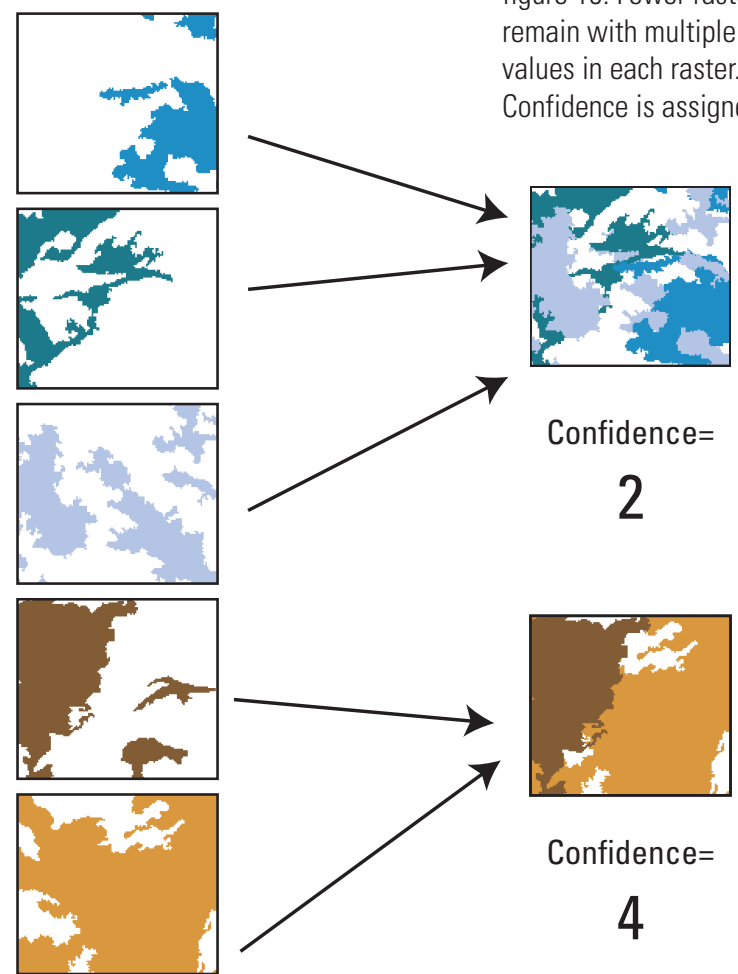

Confidence $=$

4
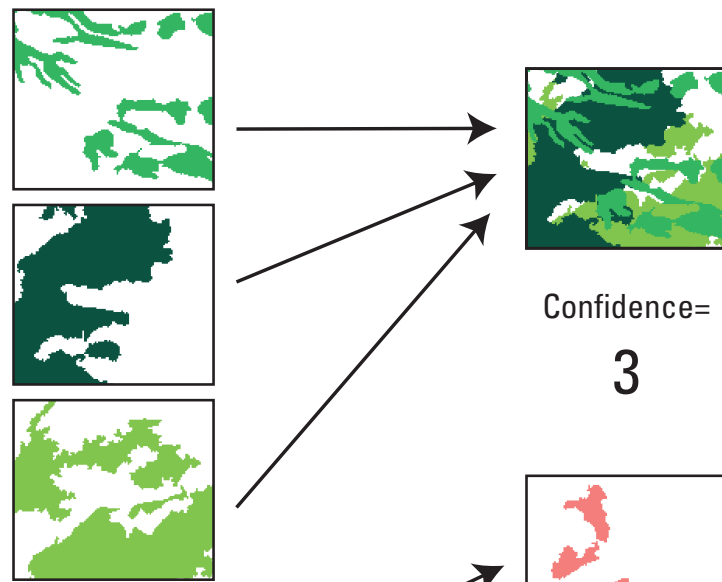

Confidence $=$

3
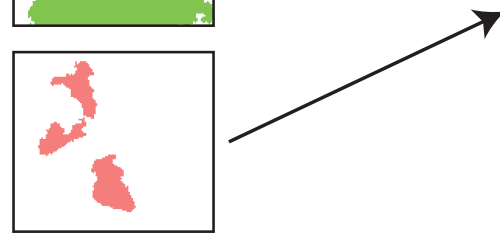

3 - Rasters are merged according to confidence. One raster remains with many pixel values.
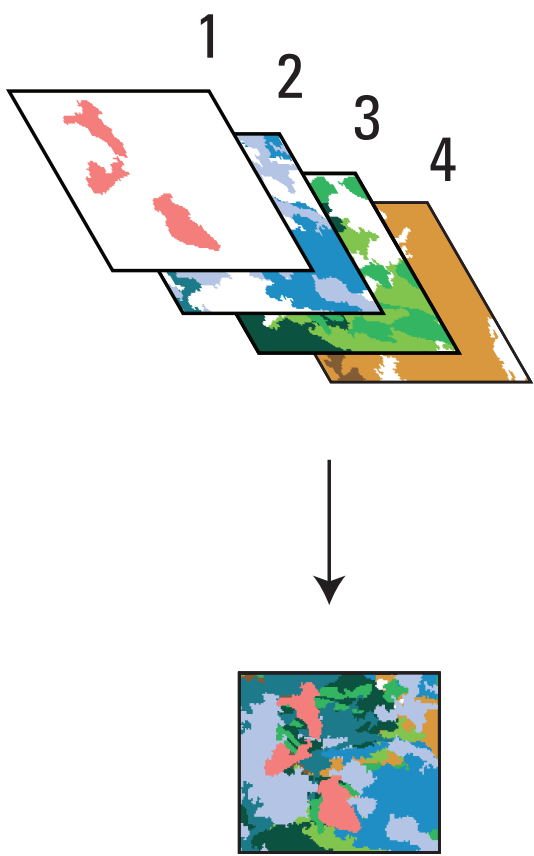

Figure 11. Raster processing workflow. 
Table 3. Summary of major reclassifications resulting from photo interpretation by study area.

[See Appendix 1 for explanations of stand names. Abbreviations ACEC, Areas of Critical Environmental Concern; NCA, National Conservation Area]

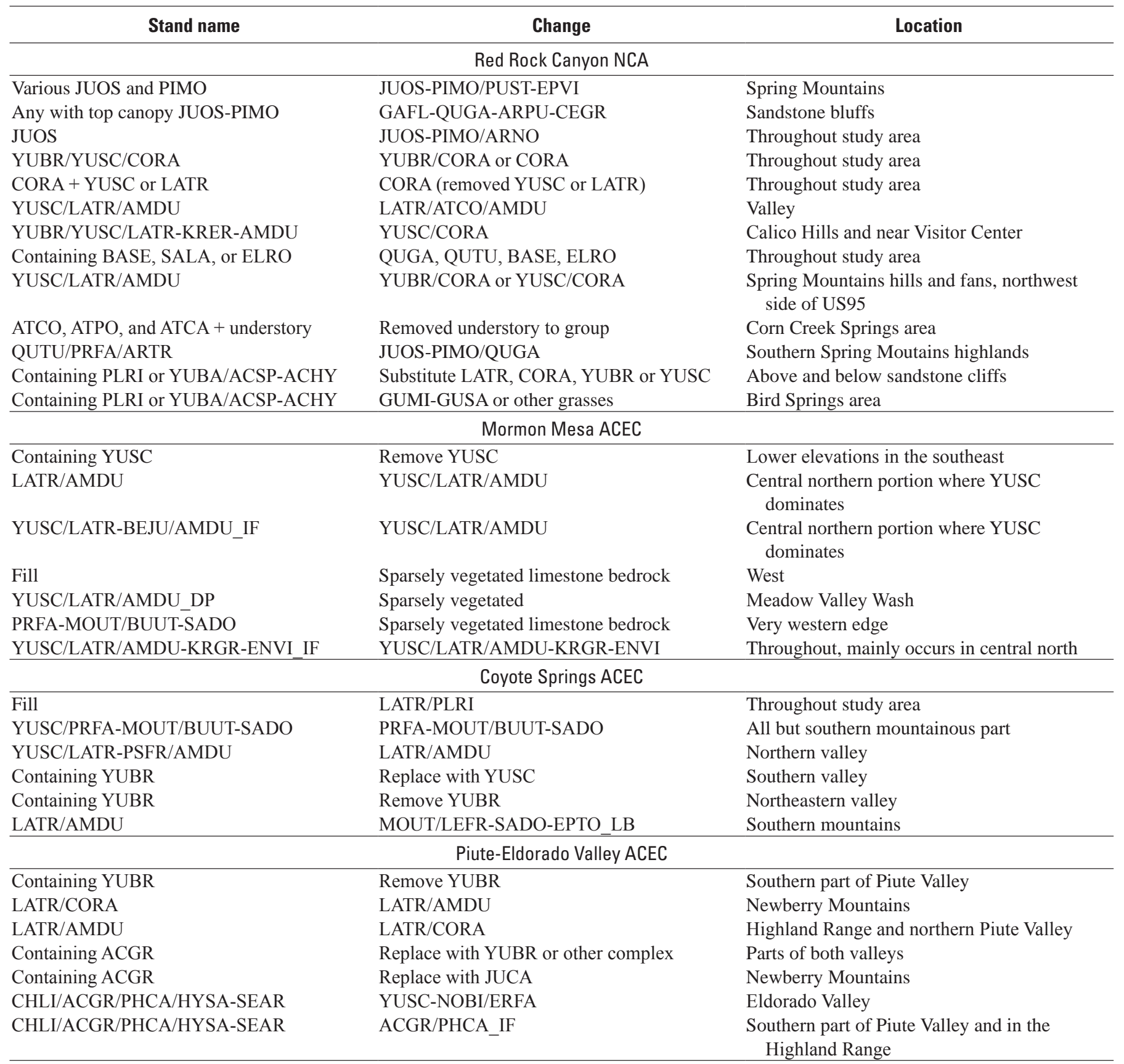




\section{Non-Vegetation Feature Delineation}

Non-vegetation land-cover features were delineated separately from the vegetation classification either by manual delineation or by FA feature extraction with heavy manual editing. Paved roads and disturbed areas were delineated from the pan-sharpened imagery. Center lines for roads were delineated and buffered with known widths depending on the number of lanes. Road-sides are cleared of debris or vegetation and sometimes sprayed with herbicide. Vegetation growing in these areas, where the natural vegetation has been disturbed, are called ruderal (a plant species that is first to colonize disturbed lands). The roads were further buffered by known right-of-way widths to include these ruderal areas. Unpaved roads and one set of railroad tracks were delineated and buffered if their width, as measured on the pan-sharpened imagery, was wider than $8 \mathrm{~m}$. Other disturbed areas that were digitized included parking areas, power lines, and remnants of mining activity.

There were a number of wildfire scars in and around the study areas. Point locations from wildfires prior to 2006 were acquired from the BLM Nevada State Office (2006). AFE models were developed and run where scars were visible on the imagery. The resulting polygons were edited to remove any areas identified as wildfire for which there was no point location from the BLM.

Several AFE models were also developed and run for the clouds and cloud shadows in the August imagery of the Mormon Mesa and Piute-Eldorado Valley ACECs. The resulting polygons were edited to remove features like shadows in the mountains and highly reflective areas in the valley. The light edges of clouds are not well defined. These areas could have incorrect land cover.

\section{Assembly of Final Data Sets}

During the final data-set assembly, all polygons from the non-vegetated feature delineation were converted to raster and merged with the final vegetation classification. Pixel values from the non-vegetated rasters replaced pixel values from the vegetation raster in the order of disturbed, wildfire scars, unpaved roads, ruderal, paved roads, and clouds. The final rasters (one for each study area) were filtered with the ERDAS "clump and eliminate" routine to remove any area smaller than the minimum mapping unit of 176 pixels (ERDAS, 2010). To maintain the road widths, the paved road map unit was not used in the filter process. The rasters were then converted to polygon vector data sets (one for each study area) in an ArcGIS geodatabase. The geodatabase contains a table that relates each map class to the NVC hierarchy from alliance to class (table 1).

\section{Results}

The final land-cover data sets are based on higherresolution imagery and more detailed vegetation data and use a smaller minimum mapping unit than previous land-cover analyses available for the study areas. The resulting data sets capture greater local variation in land cover even at equivalent levels of vegetation categorization (fig. 12) and provide previously unavailable floristic information at the finer levels of the NVC hierarchy (fig. 13). The data sets map 155 unique map classes, 67 NVC alliances, 13 NVC macrogroups, and 4 NVC classes. See table 4 for class details for each study area.

\section{Red Rock Canyon NCA}

From the 300 plot samples collected in and around the NCA, 52 AFE models were developed. Table 5 lists the map classes and the area they occupy in the final land-cover data set for Red Rock Canyon NCA. The YUBR-YUSC/CORA class is the most commonly mapped in the NCA, occupying 11,250 hectares. At the NVC alliance level, Yucca brevifolia - Coleogyne ramosissima Wooded Shrubland Alliance, Coleogyne ramosissima Shrubland Alliance, Yucca brevifolia - Larrea tridentata - Ambrosia dumosa Wooded Shrubland Alliance, and Juniperus osteosperma - (Pinus monophylla) Woodland Alliance occupy about 18,13,13, and 10 percent of the land cover, respectively. There are 5,400 hectares unclassified, or about 7 percent of the cover.

\section{Mormon Mesa ACEC}

From the 211 RACE samples in and around Mormon Mesa ACEC, 98 AFE models were created. Table 6 lists the map classes and the area they occupy in the final land-cover data set for the Mormon Mesa ACEC. The LATR/AMDU class is the most common in the ACEC, occupying 14,890 hectares. At the NVC alliance level, Larrea tridentata - Ambrosia dumosa Wooded Shrubland Alliance occupies 29 percent of land cover, followed by Yucca brevifolia Larrea tridentata - Ambrosia dumosa Wooded Shrubland Alliance, and Yucca schidigera - Larrea tridentata - Ambrosia dumosa Wooded Shrubland Alliance with 14 and 10 percent cover, respectively. There are 9,830 hectares unclassified, or about 16 percent cover. 

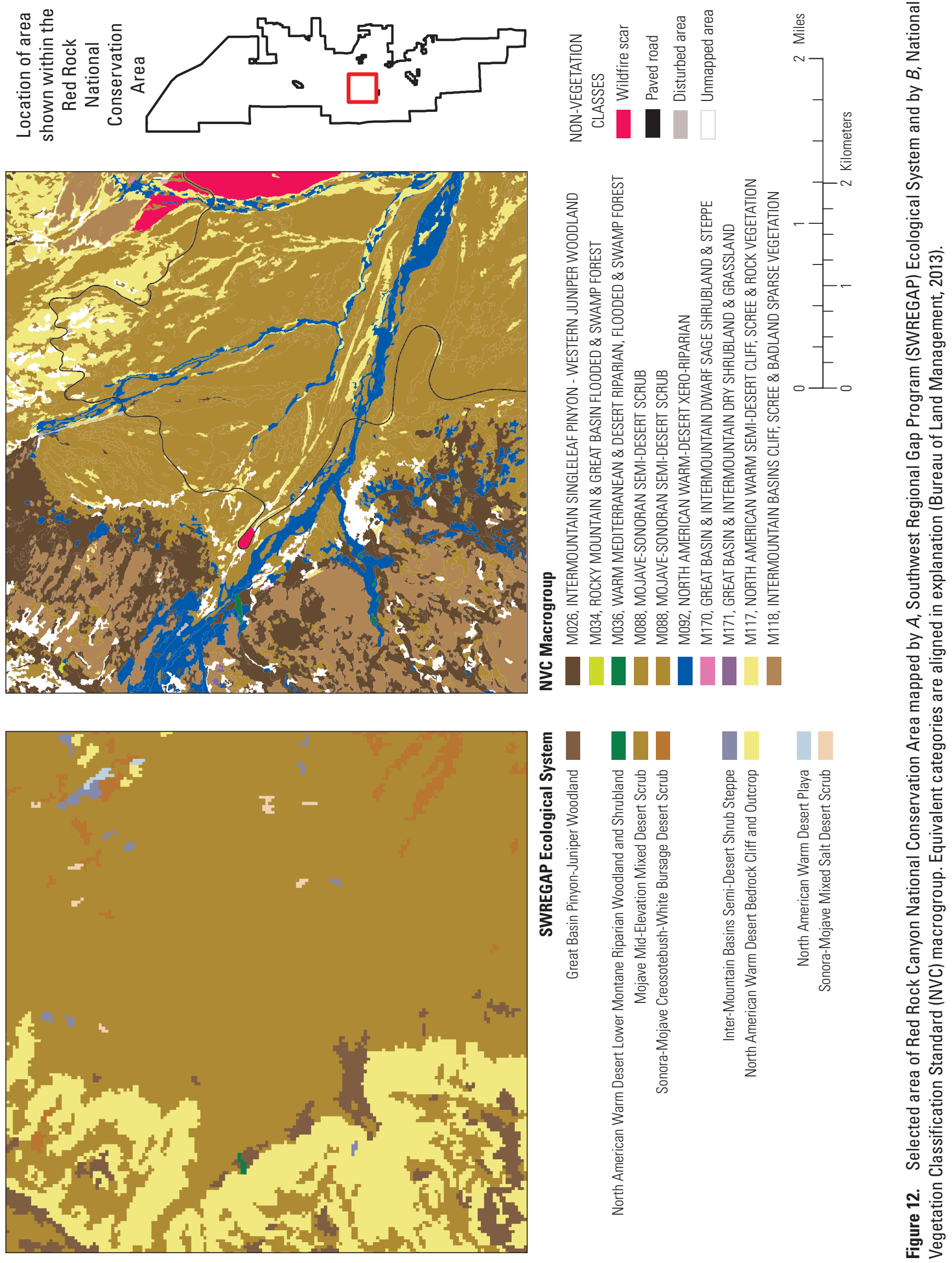

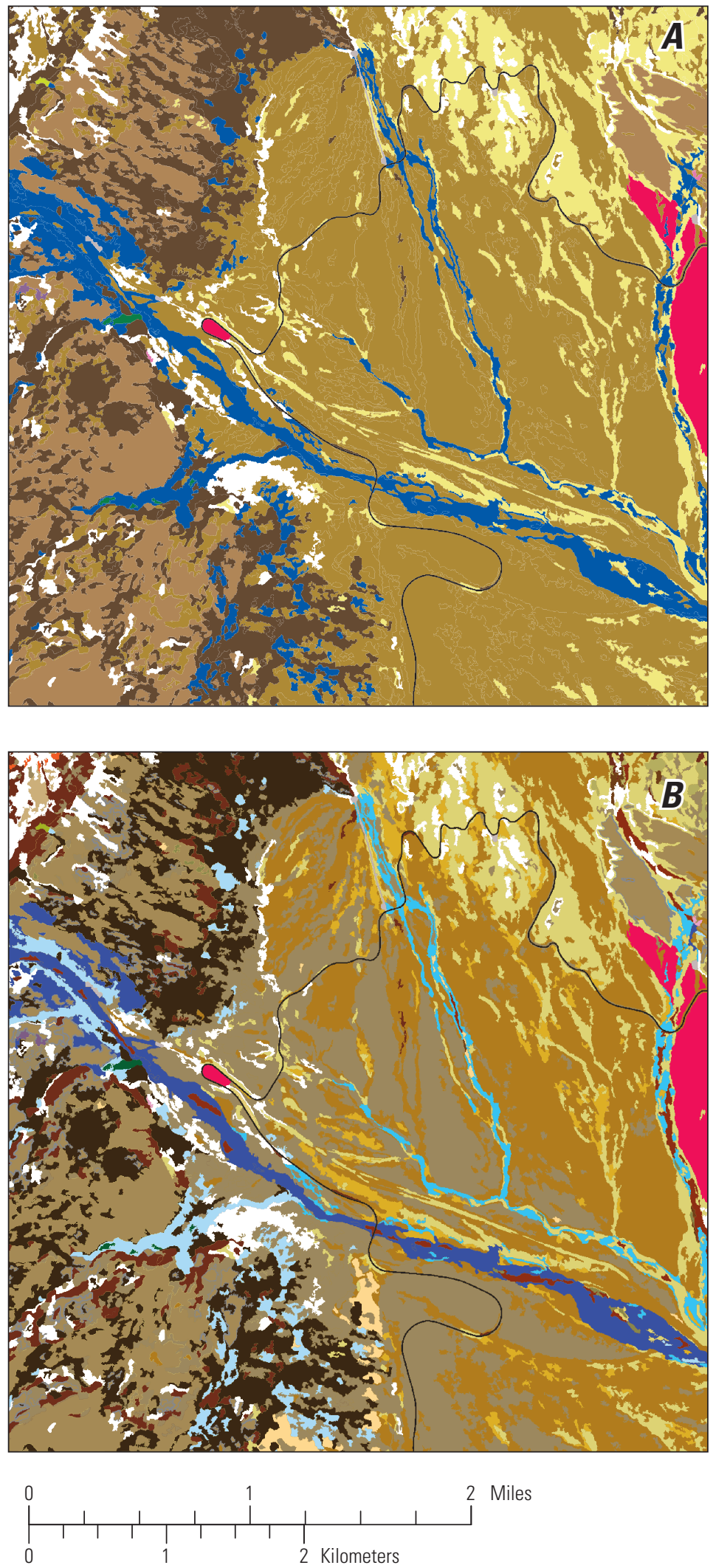

NVC Forest \& Woodland Class

M026, INTERMOUNTAIN SINGLELEAF PINYON - WESTERN JUNIPER WOODLAND

Juniperus osteosperma - (Pinus monophylla) Woodland Alliance

Juniperus osteosperma - Quercus turbinella Wooded Shrubland Alliance

M034, ROCKY MOUNTAIN \& GREAT BASIN FLOODED \& SWAMP FOREST

Quercus gambelii Temporarily Flooded Forest Alliance

M036, WARM MEDITERRANEAN \& DESERT RIPARIAN, FLOODED \& SWAMP FOREST

Salix lasiolepis Temporarily Flooded Shrubland Alliance

\section{NVC Semi-Desert Class}

M088, MOJAVE-SONORAN SEMI-DESERT SCRUB

Coleogyne ramosissima - Artemisia nova Shrubland Alliance

Coleogyne ramosissima Shrubland Alliance

Juniperus osteosperma - Coleogyne ramosissima Wooded Shrubland Alliance

Larrea tridentata - Ambrosia dumosa Shrubland Alliance

Yucca brevifolia - Coleogyne ramosissima Wooded Shrubland Alliance

Yucca brevifolia - Larrea tridentata - Ambrosia dumosa Wooded Shrubland Alliance

Yucca schidigera - Coleogyne ramosissima Wooded Shrubland Alliance

Yucca schidigera - Larrea tridentata - Ambrosia dumosa Wooded Shrubland Alliance

M092, NORTH AMERICAN WARM-DESERT XERO-RIPARIAN

Chilopsis linearis Intermittently Flooded Shrubland Alliance

Hymenoclea salsola Intermittently Flooded Shrubland Alliance Quercus turbinella Intermittently Flooded Wooded Shrubland Alliance

M170, GREAT BASIN \& INTERMOUNTAIN DWARF SAGE SHRUBLAND \& STEPPE

Artemisia nova Shrubland Alliance

M171, GREAT BASIN \& INTERMOUNTAIN DRY SHRUBLAND \& GRASSLAND

Location of area shown within the

Red Rock

National

\section{NVC Nonvascular and Sparse}

Vegetation Class

M117, NORTH AMERICAN WARM SEMII-DESERT CLIFF, SCREE \& ROCK VEGETATION

Sparsely Vegetated Alliance

Sparsely Vegetated Warm Desert Limestone Bedrock Alliance

Sparsely Vegetated Warm Desert Talus Slope Alliance

M118, INTERMOUNTAIN BASINS CLIFF, SCREE \& BADLAND

SPARSE VEGETATION

Sparsely Vegetated Montane Sandstone Bedrock Alliance

NON-VEGETATION CLASSES

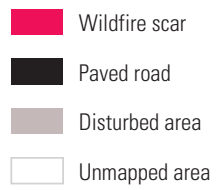

Conservation

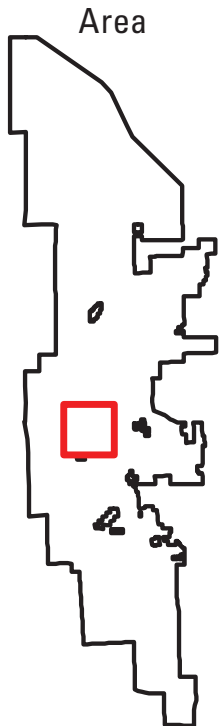

Figure 13. Selected area of Red Rock Canyon National Conservation Area mapped by $A$, National Vegetation Classification Standard (NVC) macrogroup and $B, \mathrm{NVC}$ alliance. 
Table 4. Number of unique classes and associated National Vegetation Classification Standard (NVC) hierarchy categories by study area.

[Map class counts include 6 non-vegetated classes. Abbreviations ACEC, Area of Critical Environmental Concern; NCA, National Conservation Area]

\begin{tabular}{lcccc}
\hline \multicolumn{1}{c}{ Study area } & Map classes & NVC alliances & NVC macrogroups & NVC classes \\
\hline Red Rock Canyon NCA & 55 & 37 & 27 & 4 \\
Mormon Mesa ACEC & 69 & 13 & 5 & 3 \\
Coyote Springs ACEC & 26 & 16 & 4 & 3 \\
Piute-Eldorado Valley ACEC & 49 & 67 & 13 & 2 \\
Total unique for all areas & 155 & & 4 \\
\hline
\end{tabular}




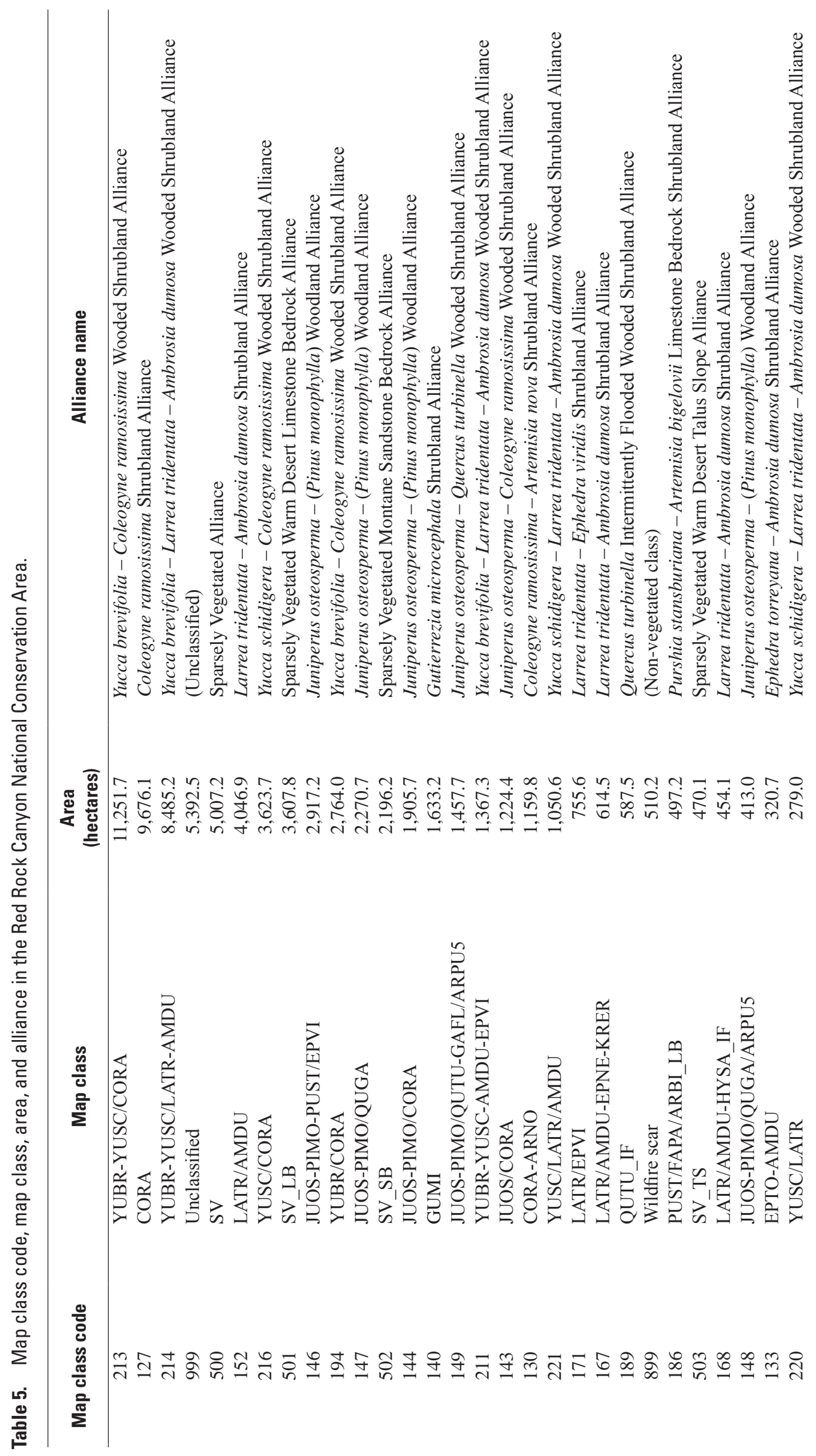




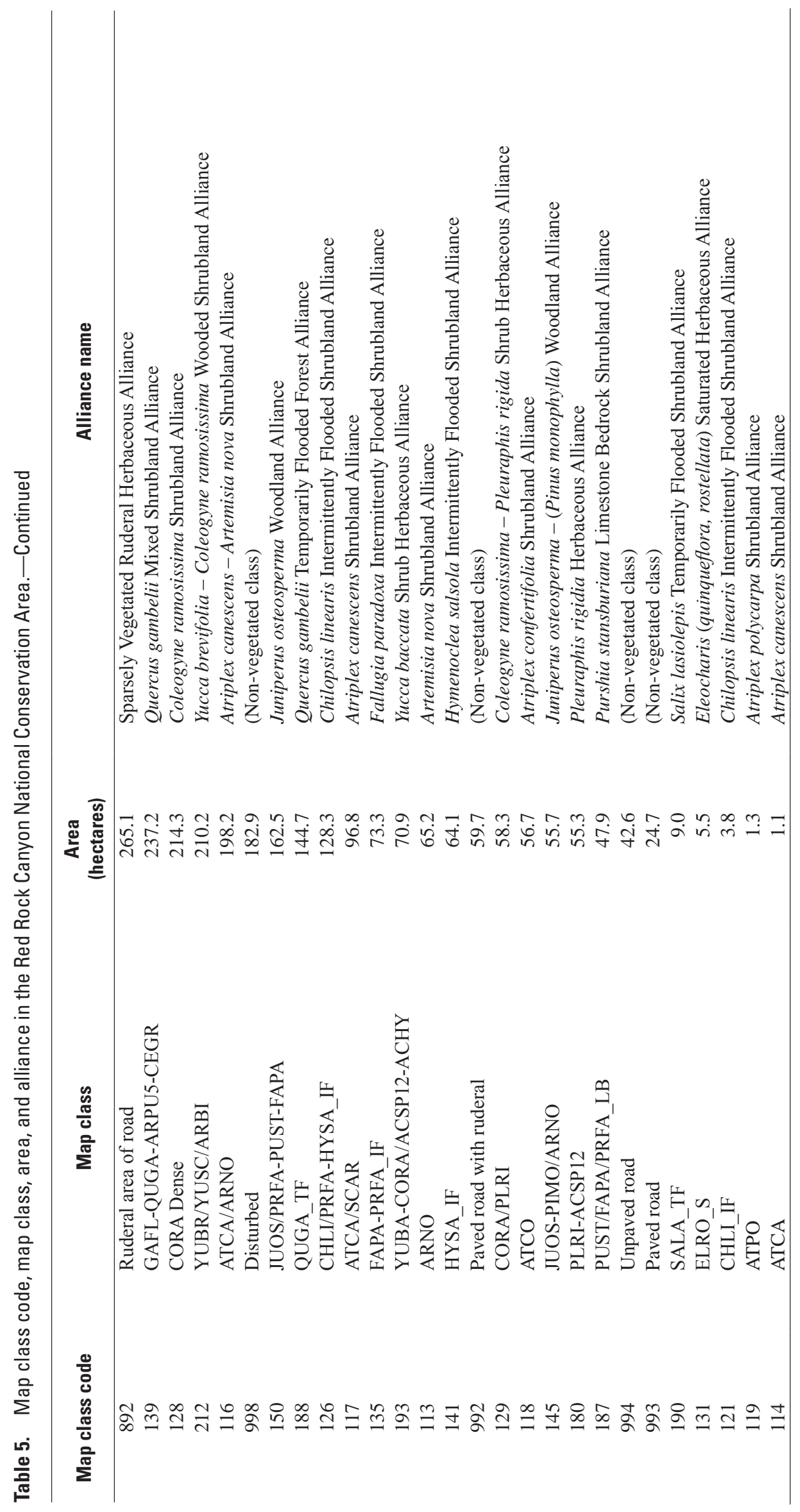




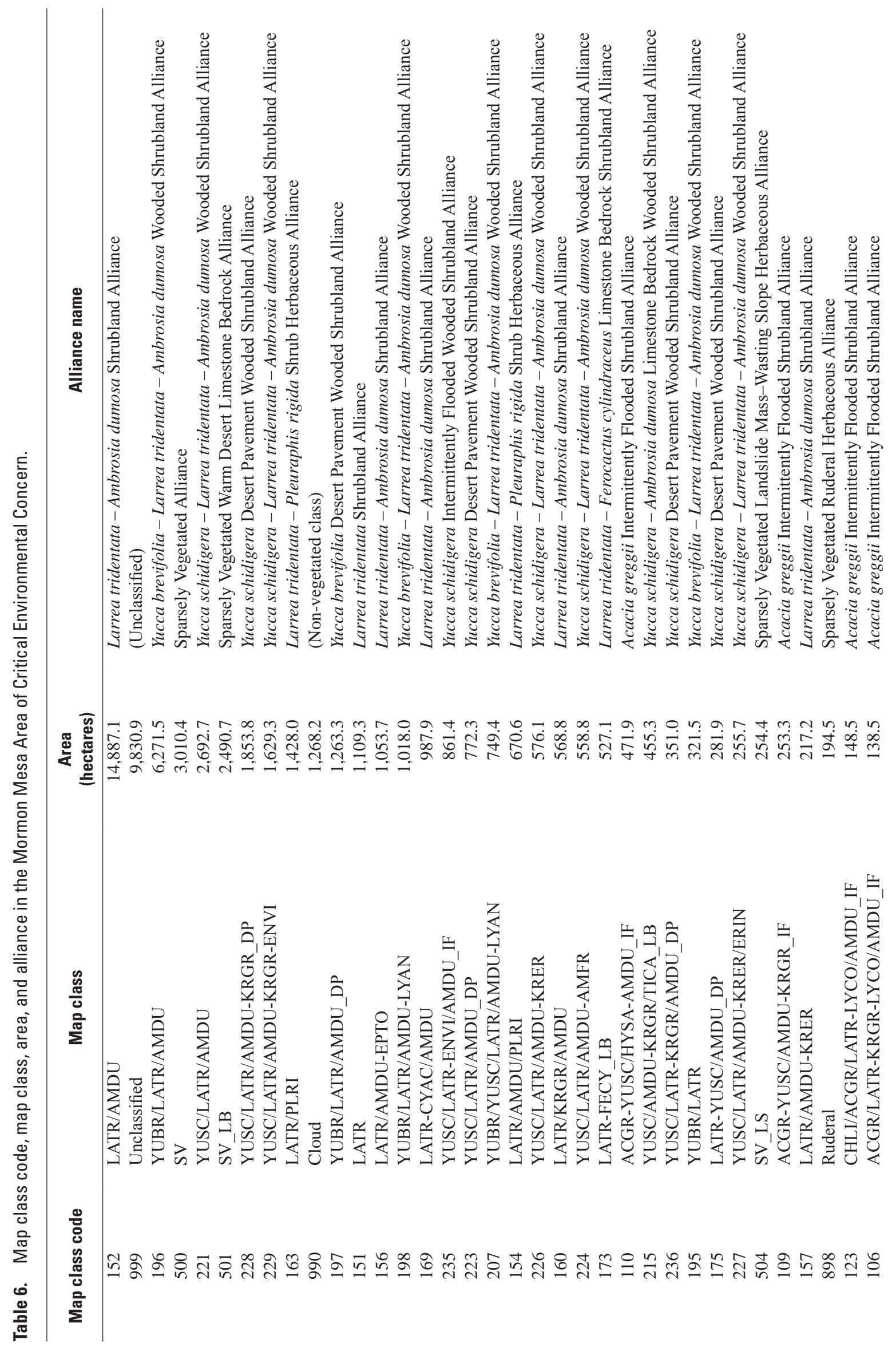




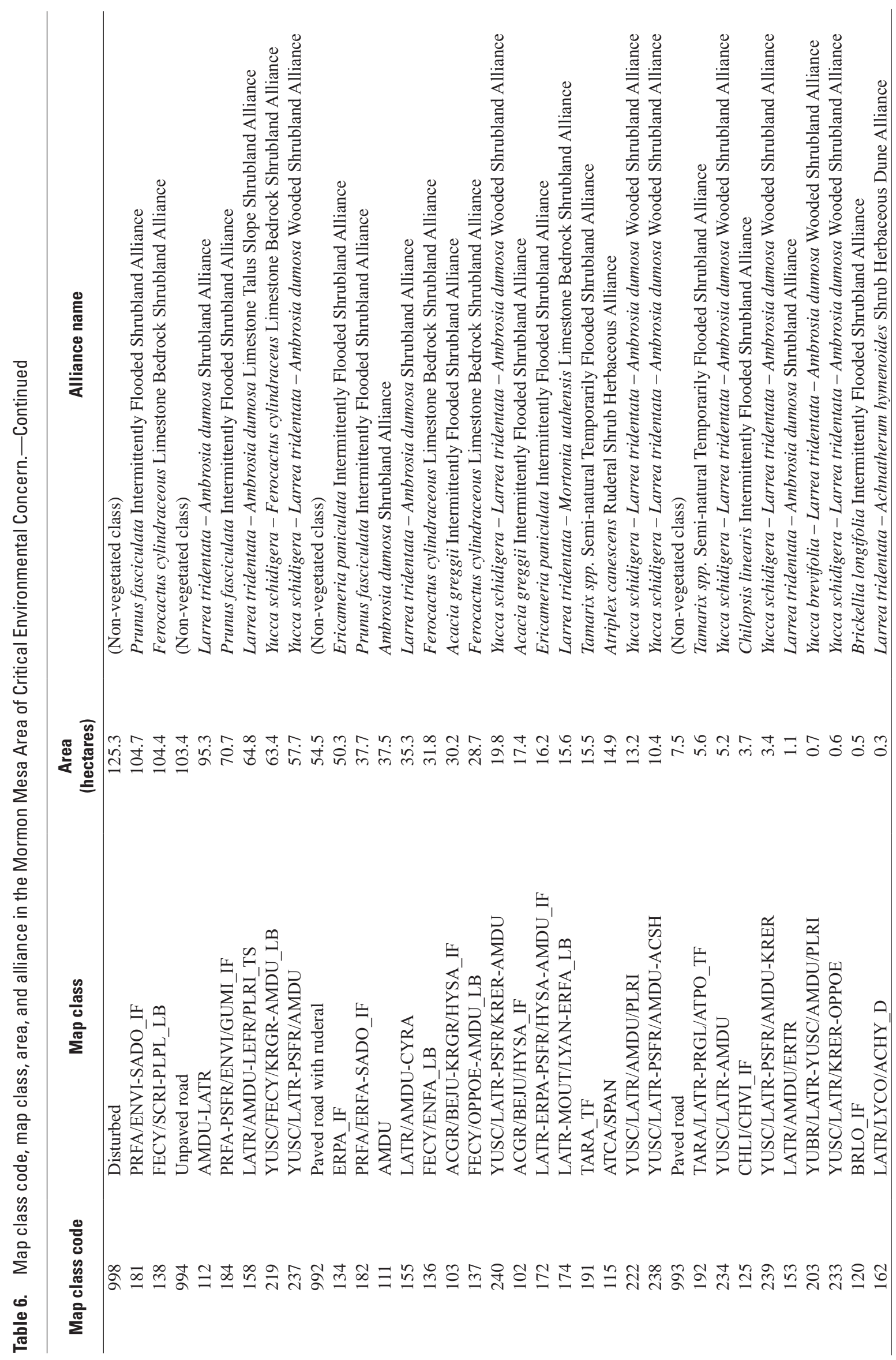




\section{Coyote Springs ACEC}

From the 108 RACE samples in and around the Coyote Springs ACEC, 27 AFE models were developed. Table 7 lists the map classes and the area they occupy in the final land-cover data set for the Coyote Springs ACEC. The LATR/AMDU class is the most common in the ACEC, occupying 4,900 hectares. At the alliance level, Yucca schidigera - Larrea tridentata - Ambrosia dumosa Wooded Shrubland Alliance and Larrea tridentata - Ambrosia dumosa Wooded Shrubland Alliance occupy the most cover with 30 and 26 percent, respectively. There are 1,960 hectares unclassified, or about 9 percent.

\section{Piute-Eldorado Valley ACEC}

From the 530 RACE samples in and around the PiuteEldorado ACEC, 59 AFE models were developed. Table 8 lists the map classes and the area they occupy in the final land-cover data set for the Piute-Eldorado Valley ACEC. The LATR/AMDU class is the most common in the ACEC, occupying 59,600 hectares. At the NVC alliance level, Larrea tridentata - Ambrosia dumosa Shrubland Alliance is dominant with 46 percent land cover. There are 6,920 hectares unclassified, or about 5 percent cover.

\section{Map Accuracy}

A statistical, quantitative accuracy assessment was not within the scope of this study. A stratified random or equalized random accuracy assessment at the map class level would require about a thousand field samples randomly distributed throughout the study areas. SWReGAP used a less statistically robust method of withholding a portion of field samples to be used for accuracy assessment (Kepner and others, 2005). The SWReGAP method was not feasible for this study because field sampling and land-cover analyses were ongoing simultaneously, and all field samples available were used for evaluating and validating the AFE model outputs.
The SWReGAP field sample database for Nevada (Kepner, 2005) is the only known source of freely available, independent field samples for the study areas. Of the 35 SWReGAP samples that fall within the study areas, 28 samples, or 80 percent, agree with the final land-cover datasets at the NVC macrogroup level. All of the matching samples are in the Mojave-Sonoran Semi-Desert Scrub Macrogroup, the most mapped unit in Clark County by SWReGAP. The samples are not evenly distributed geographically or by map class. This measure qualitatively supports, but in no way confirms, the hypothesis that the final land-cover data sets are at least as accurate as previously available products.

Accuracy can be evaluated by use. The map class boundaries were only slightly modified from the original feature extraction outputs by the filtering process. Therefore, it is believed the boundaries correspond well to features on the ground. With additional field data, the map classes to which features belong can be confirmed or updated, and map accuracy improved.

\section{Summary}

Existing land-cover data sets for most areas in Clark County, Nevada, are based on 30-meter Landsat imagery and generalized vegetation classes. These data sets are insufficient for land managers to make decisions in areas meant to protect natural resources and wildlife, in particular the desert tortoise (Gopherus agassizii) and its habitat.

DigitalGlobe's QuickBird satellite imagery was used as the high-resolution base imagery for classification. Feature Analyst feature extraction software was used as the classification tool. More than 1,000 vegetation samples were collected in accordance with NVC naming hierarchy and sampling protocol, and from them, more than 200 AFE models were created to produce the vegetation map classes in the final landcover data sets. These data sets also include hand-edited map units of paved roads, disturbed areas, and areas damaged by wild fires. These maps are much more detailed than previously available land-cover maps, both in resolution and in vegetation map classes. 


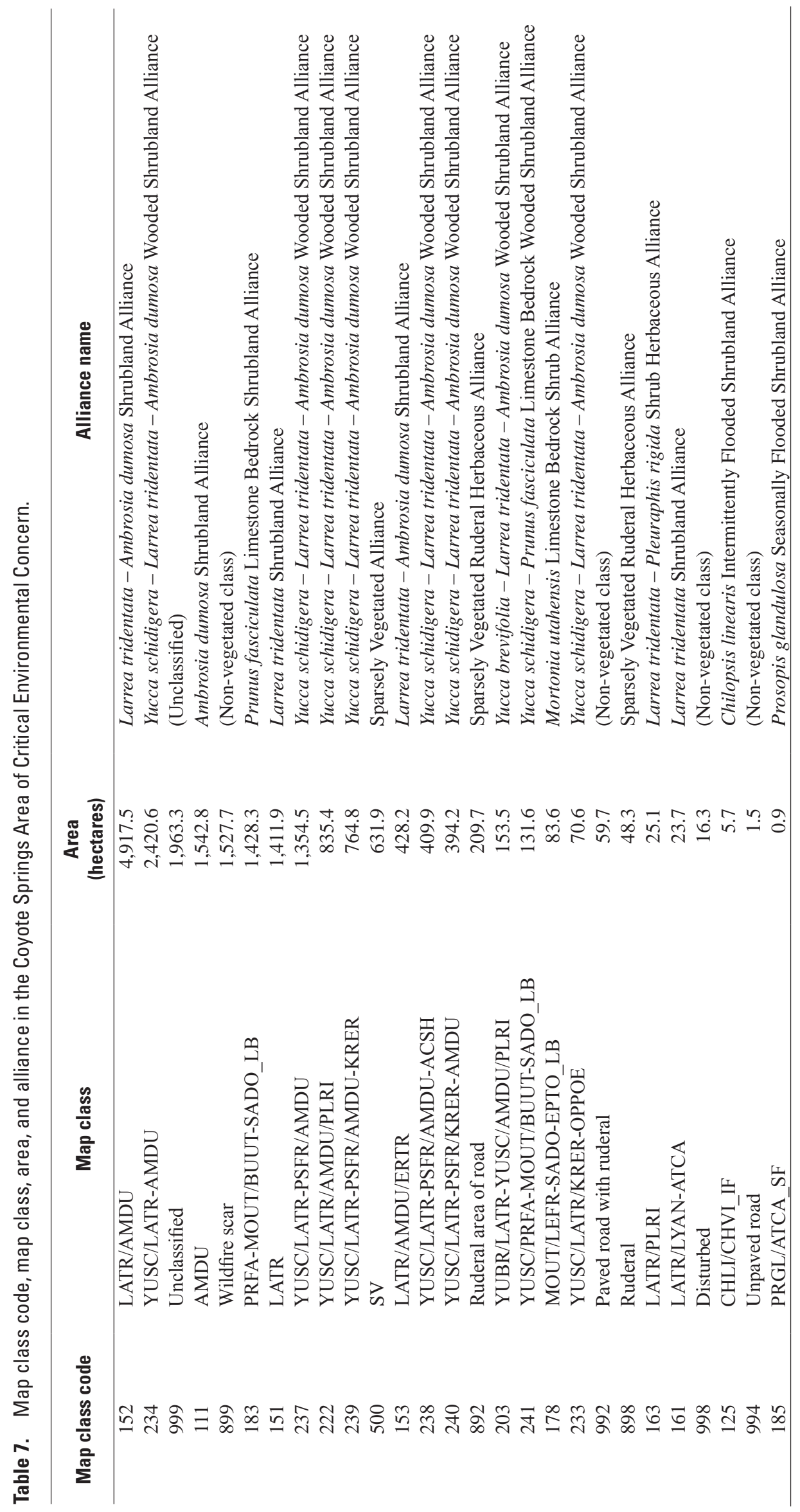




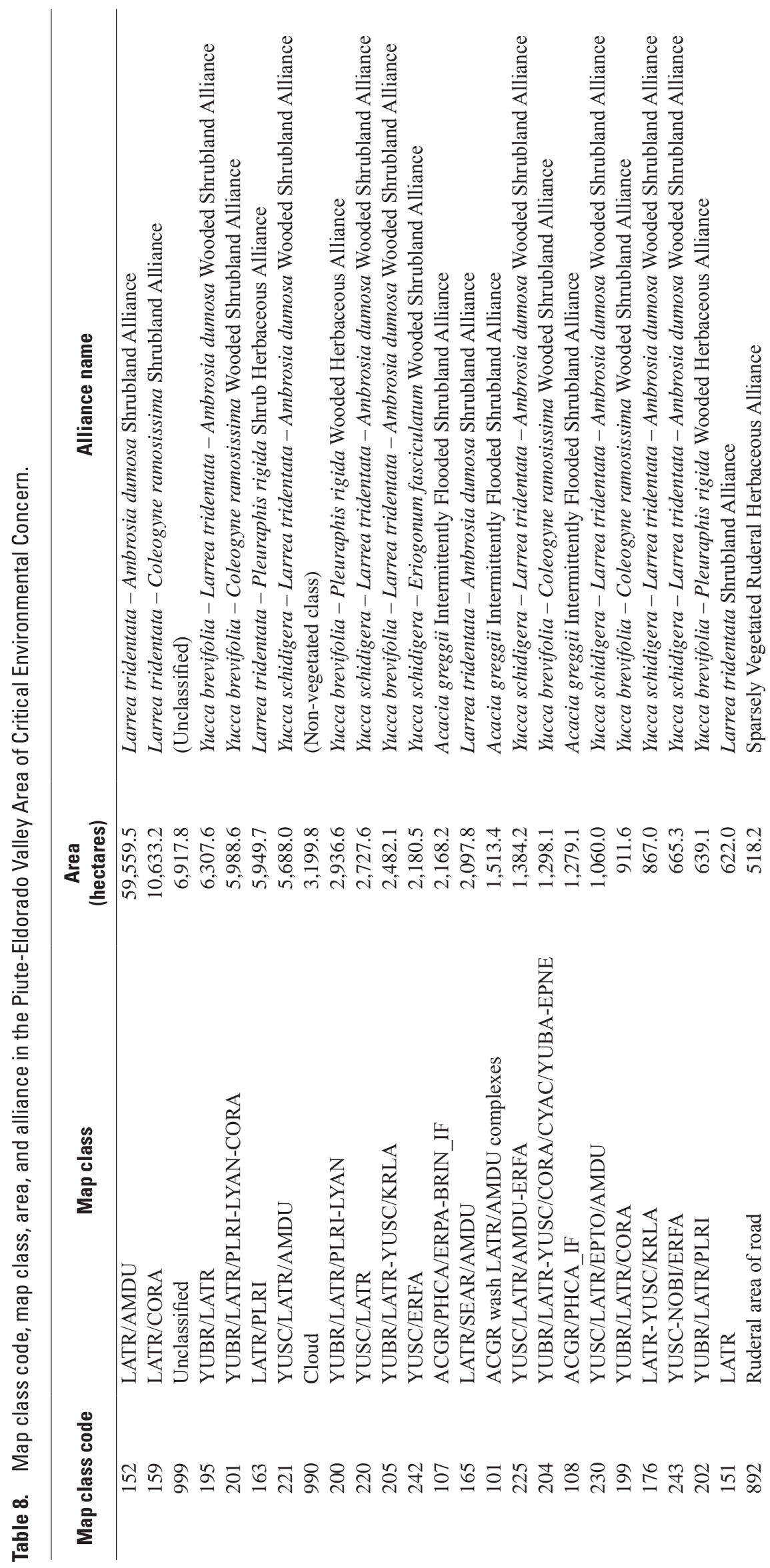




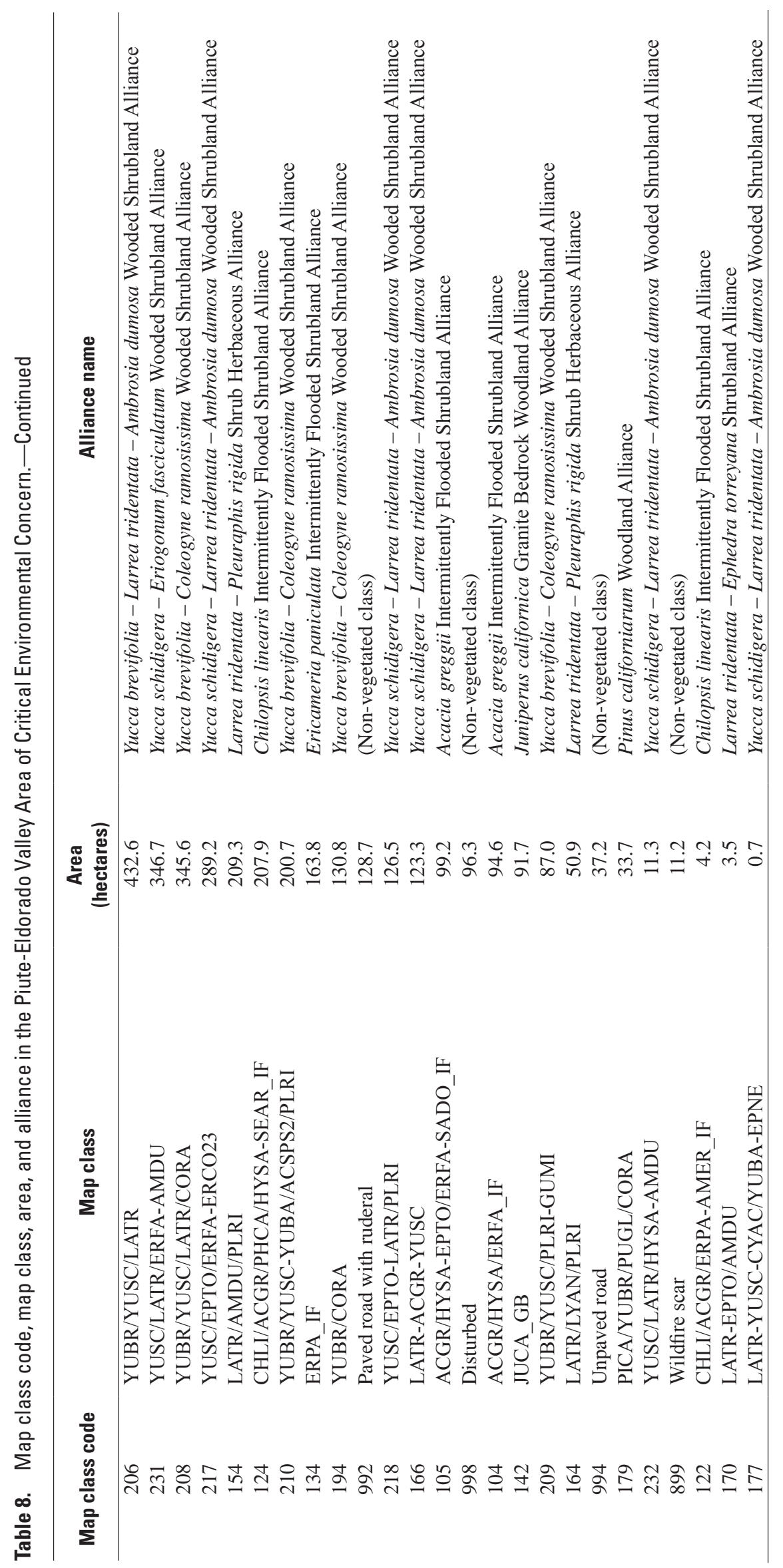




\section{References Cited}

Brussard, P.F., Charlet, D.A., and Dobkin, D., 1999, The Great Basin-Mojave Desert region, in Mac, M.J., Opler, P.A., Puckett-Haecker, C.E.and Doran, P.D. (eds), The status and trends of the Nation's biological resources: U.S. Department of the Interior, U.S. Geological Survey, Reston, Virginia, p. 505-542.

Bureau of Land Management, 1980, Final environmental assessment NV-050-9-30: Oil and gas leasing in the Red Rock Canyon recreation lands, 249 p.

Bureau of Land Management, 2006, NV_Fire_history layers: Nevada State Office ACEC Geospatial Data web page, accessed April 18, 2013, at http://www.blm.gov/nv/st/en/ prog/more_programs/geographic_sciences/gis/geospatial_ data.html.

Bureau of Land Management, 2013, Crosswalk from ecological systems to NVCS macrogroups, attachment 4 in memo: The National Vegetation Classification and Associated Mapping Standards for Bureau of Land Management planning documents and assignment of State-level Vegetation Classification Data Stewards, accessed September 16, 2013, at http://www.blm.gov/wo/st/en/info/regulations/Instruction Memos_and_Bulletins/national_instruction/2013/im_2013111_the_national.html.

Charlet, D.A., Damar, N.A., and Leary, P.J., 2014, Vegetation database for land-cover mapping, Clark and Lincoln Counties, Nevada: U.S. Geological Survey, Data Series 827, 17 p., http://pubs.usgs.gov/ds/827.

Comer, P., Faber-Langendoen, D., Evans, R., Gawler, S., Josse, C., Kittel, G., Menard, S., Pyne, M., Reid, M., Schulz,K., Snow, K., and Teague, J., 2003. Ecological systems of the United States: A working classification of U.S. terrestrial systems: NatureServe, Arlington, Virginia, accessed April 18, 2013, at http://www.natureserve.org/ library/usEcologicalsystems.pdf.

Daly, C., Gibson, W., Doggett, M., Smith, J., and Taylor, G., 2004, Up-to-date monthly climate maps for the conterminous United States, 14th AMS Conference on Applied Climatology: American Meteorological Society, Seattle, Washington, January 13-16, 2004, 8 p.

ERDAS, Inc., 2010, ERDAS Field Guide, accessed April 18, 2013, at http://geospatial.intergraph.com/fieldguide/ wwhelp/wwhimpl/js/html/wwhelp.htm.

ESRI, 2011, ArcGIS Desktop 9.3 Help, accessed May 21, 2013, at http://webhelp.esri.com/arcgisdesktop/9.3/index. cfm.
Fenneman, N.M and Johnson, D.W., 1946, Physiographic divisions of the conterminous United States: U.S. Geological Survey, USGS special map, accessed December 6, 2012 at http://water.usgs.gov/lookup/getspatial?physio.

Federal Geographic Data Committee, 2008, National vegetation classification standard, version 2, FGDCSTD-005-2008, accessed December 6, 2012, at http://www. fgdc.gov/standards/projects/FGDC-standards-projects/ vegetation/NVCS_V2_FINAL_2008-02.pdf.

Geosystems, 2013, ATCOR for ERDAS IMAGINE produce website, accessed August 21, 2013, at http://www. geosystems.de/atcor/index.html.

Heaton, J.S., Miao, X., Von Seckendorff, K., Charlet, D. Grimmer, A., Patil, R., 2011, Final vegetation GIS data delivery: final report. Report to Clark County MSHCP 2005-UNR578:D21.

Homer, C.H., Fry, J.A., and Barnes C.A., 2012, The National Land Cover Database, U.S. Geological Survey Fact Sheet 2012-3020, 4 p., accessed December 6, 2012, at http://pubs. usgs.gov/fs/2012/3020/fs2012-3020.pdf.

Kepner, W.G., 2005, Landcover Training Site Database for Nevada (2002-2004), accessed September 13, 2013, at http://earth.gis.usu.edu/swgap/data/field_databases/ nv/NVGap_Database/documents/NV_Gap_Database_ metadata.html.

Kepner, W.G., Sajwaj, T.D., Bradford, D.F., and Evanson, E.J.. 2005, Nevada geospatial data browser: Las Vegas, Nev., U.S. Environmental Protection Agency, Office of Research and Development, EPA/600/C-05/005, accessed May 4, 2007, at http://www.epa.gov/nerlesd1/land-sci/gap.htm.

Longwell, C.R., Pampeyan, E.H., Bowyer, B., and Roberts, R.J., 1965, Geology and Mineral Deposits of Clark County, Nevada. Nevada Bureau of Mines and Geology, Bulletin 62, 218 p., with 1:250,000 scale geologic map.

Maxwell, J., Gergely, K., and Aycrigg, J., 2010, Gap analysis bulletin, vol. 18: U.S. Geological Survey, 47 p., accessed December 6, 2012, at http://www.gap.uidaho.edu/ Bulletins/18/GAPBulletin18.pdf.

Prior-Magee, J.S., Boykin, K.G., Bradford, D.F., Kepner, W.G., Lowry, J.H., Schrupp, D.L., Thomas, K.A., and Thompson, B.C., eds., 2007, Southwest Regional Gap Analysis Project Final Report: U.S. Geological Survey, Gap Analysis Program, Moscow, Id., at ftp://ftp.gap.uidaho. edu/products/regional/southwest/Report/SWReGAP\%20 Final\%20Report.pdf. 
RECON Environmental, Inc., 2000, Final Clark County multiple species habitat conservation plan and environmental impact statement for issuance of a permit to allow incidental take of 79 species in Clark County, Nevada: Report to Clark County Department of Comprehensive Planning and U.S. Fish and Wildlife Service.

Shreve, F., 1942, The desert vegetation of North America: The Botanical Review, v. 8, no. 4, p. 195-246.

Smith, D.S. and Nowak, R.S., 1990, Ecophysiology of plants in the intermountain lowlands, chap. 6 in Osmond, C.B., and others, eds., Plant biology of the Basin and Range: New York, NY, Springer Verlag, p. 179-241.

U.S. Department of Agriculture, 2013, The PLANTS database: National Resources Conservation Service, National Plant Data Team, Greensboro, NC, 27401-4901 USA, accessed April 18 2013, http://plants.usda.gov.

Visual Learning Systems, Inc., 2008, Feature Analyst 4.2 for ArcGIS Reference Manual, 354 p., accessed April 18, 2013, at http://www.featureanalyst.com/feature_analyst/ publications/manuals/FA_4.2_RELEASE/FA_4.2_ Reference_arc_040908_RELEASE.pdf. 
Land-Cover Mapping 


\section{Appendix}


Appendix 1. Complete List of Species Symbols and Abbreviations Used in the Data Sets 
Table 1-1. Complete list of species symbols and abbreviations used in the data sets.

[Abbreviations NRCS, Natural Resources Conservation Service; USDA, U.S. Department of Agriculture]

\begin{tabular}{|c|c|c|c|}
\hline $\begin{array}{l}\text { Stand name code for } \\
\text { azonal feature }\end{array}$ & Azonal feature & $\begin{array}{l}\text { Stand name symbol for } \\
\text { vegetation species }\end{array}$ & $\begin{array}{c}\text { USDA/NRCS species name } \\
\text { ('U.S. Department of Agriculture, 2013) }\end{array}$ \\
\hline DP & (Desert pavement) & ARTRT & Artemisia tridentata tridentata \\
\hline $\mathrm{D}$ & (Dune) & ARTRW & Artemisia tridentata wyomingensis \\
\hline G_B & (Gravel barrens) & ATCA & Atriplex canescens \\
\hline IF & (Intermittently flooded) & ATCO & Atriplex confertifolia \\
\hline $\mathrm{PN}$ & (Petrocaclic nodules) & АТРО & Atriplex polycarpa \\
\hline Playa & (Playa) & BASA & Baccharis salicifolia \\
\hline QB & (Quartzite bedrock) & BASE & Baccharis sergiloides \\
\hline SB & (Sandstone bedrock) & BAMU & Baileya multiradiata \\
\hline $\mathrm{S}$ & (Saturated) & BEJU & Bebbia juncea aspera \\
\hline $\mathrm{SF}$ & (Seasonally flooded) & BOGR & Bouteloua gracilis \\
\hline TS & (Talus slope) & BRCA & Brickellia californica \\
\hline $\mathrm{TF}$ & (Temporarily flooded) & BRGR & Brickellia grandiflora \\
\hline TB & (Tuff bedrock) & BRIN & Brickellia incana \\
\hline VB & (Volcanic bedrock) & BRLO & Brickellia longifolia \\
\hline $\begin{array}{l}\text { Stand name symbol for } \\
\text { vegetation species }\end{array}$ & $\begin{array}{c}\text { USDA/NRCS species name } \\
\text { ('U.S. Department of Agriculture, 2013) }\end{array}$ & $\begin{array}{l}\text { BRMI } \\
\text { BROB } \\
\text { BRCI }\end{array}$ & $\begin{array}{l}\text { Brickellia microphylla watsonii } \\
\text { Brickellia oblongifolia } \\
\text { Bromus ciliatus }\end{array}$ \\
\hline $\mathrm{ABCO}$ & Abies concolor concolor & BRMA & Bromus rubens \\
\hline ACGR & Acacia greggii & BRTE & Bromus tectorum \\
\hline ACSH & Acamptopappus shockleyi & BUUT & Buddleja utahensis \\
\hline ACSPS2 & Acamptopappus sphaerocephalus & CALA & Calylophus lavandulifolius \\
\hline ACGL & Acer glabrum diffusum & CANE & Carex nebrascensis \\
\hline AMER & Ambrosia eriocentra & CELE & Cercocarpus ledifolius intercedens \\
\hline AMUT & Amelanchier utahensis (sensu lato) & CHLI & Chilopsis linearis arcuata \\
\hline AMFR & Amphipappus fremontii fremontii & CHGR & Chrysothamnus gramineus \\
\hline AMTO & Amsonia tomentosa & CHVI & Chrysothamnus viscidiflorus viscidiflorus \\
\hline ANCA & Anemopsis californica & & (sensu lato) \\
\hline ANSC & Angelica scabrida & CIAR & Cirsium arizonicum \\
\hline ANRO & Antennaria rosea & CIEAC & Cirsium clokeyi \\
\hline ANSO & Antennaria soliceps & CLLI & Clematis ligusticifolia \\
\hline AQFO & Aquilegia formosa & CORA & Coleogyne ramosissima \\
\hline ARPU5 & Arctostaphylos pungens & COUM & Comandra umbellata pallida \\
\hline ARMU & Argemone munita & CUSA & Cuscuta salina \\
\hline ARPUP6 & Aristida purpurea purpurea & CYAC & Cylindropuntia acanthocarpa \\
\hline ARBI & Artemisia bigelovii & CYBI & Cylindropuntia bigelovii \\
\hline ARDR & Artemisia dracunculus & & \\
\hline ARMI & Artemisia michauxiana & & \\
\hline ARNO & Artemisia nova & & \\
\hline ARTR & Artemisia tridentata & & \\
\hline
\end{tabular}


Table1-1. Complete list of species symbols and abbreviations used in the data sets.-Continued

[Abbreviations NRCS, Natural Resources Conservation Service; USDA, U.S. Department of Agriculture]

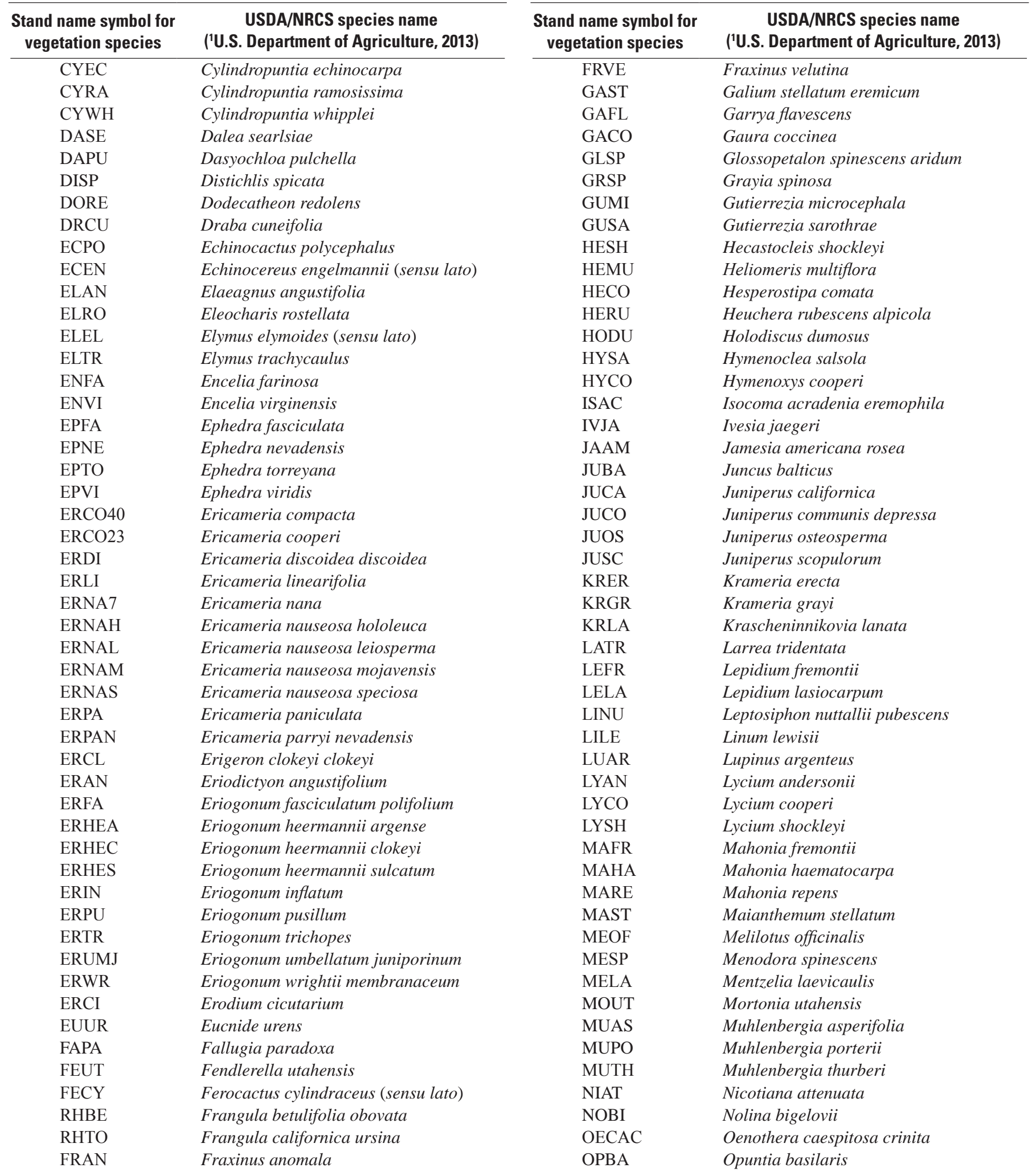


Table 1-1. Complete list of species symbols and abbreviations used in the data sets. - Continued

[Abbreviations NRCS, Natural Resources Conservation Service; USDA, U.S. Department of Agriculture]

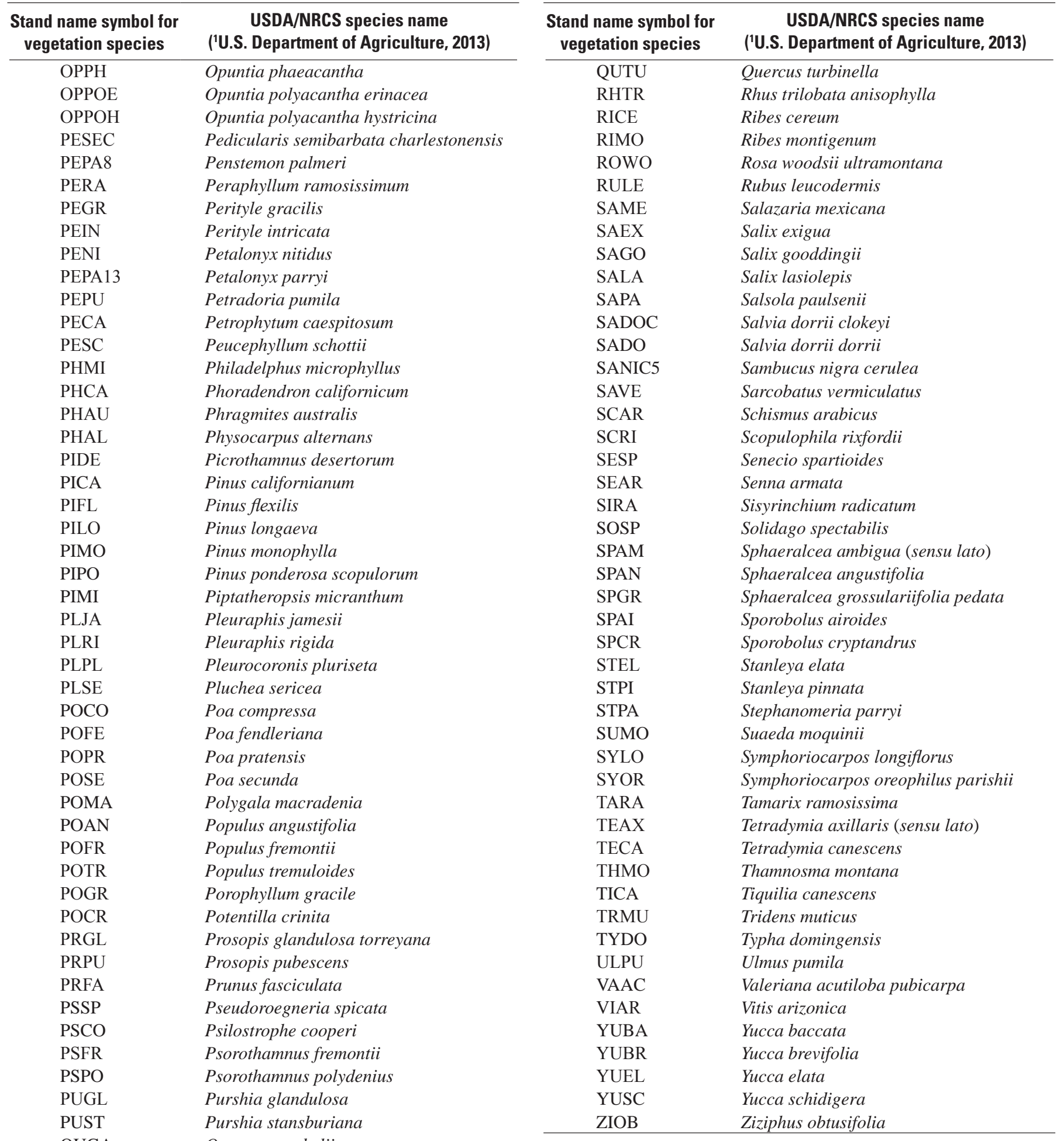

${ }^{1}$ U.S. Department of Agriculture, 2013, USDA/NRCS PLANTS Database: National Plant Data Team, Greensboro, NC 27401-4901 USA, accessed April 18, 2013, at http://plants.usda.gov. 
Table 2-1. Field samples from Red Rock National Conservation Area used as training input for Feature Analyst automated feature extraction models.

[Source: Charlet, D.A., Leary, P.J., and Damar, N.A., 2014, Vegetation database for land-cover mapping, Clark and Lincoln Counties, Nevada: U.S. Geological Survey, Data Series 827, 17 p., http://dx.doi.org/10.3133/ds827: Sample ID, Unique number used to identify sample in field sample database; Stand name, Descriptor for sample based on dominant species in each canopy layer.]

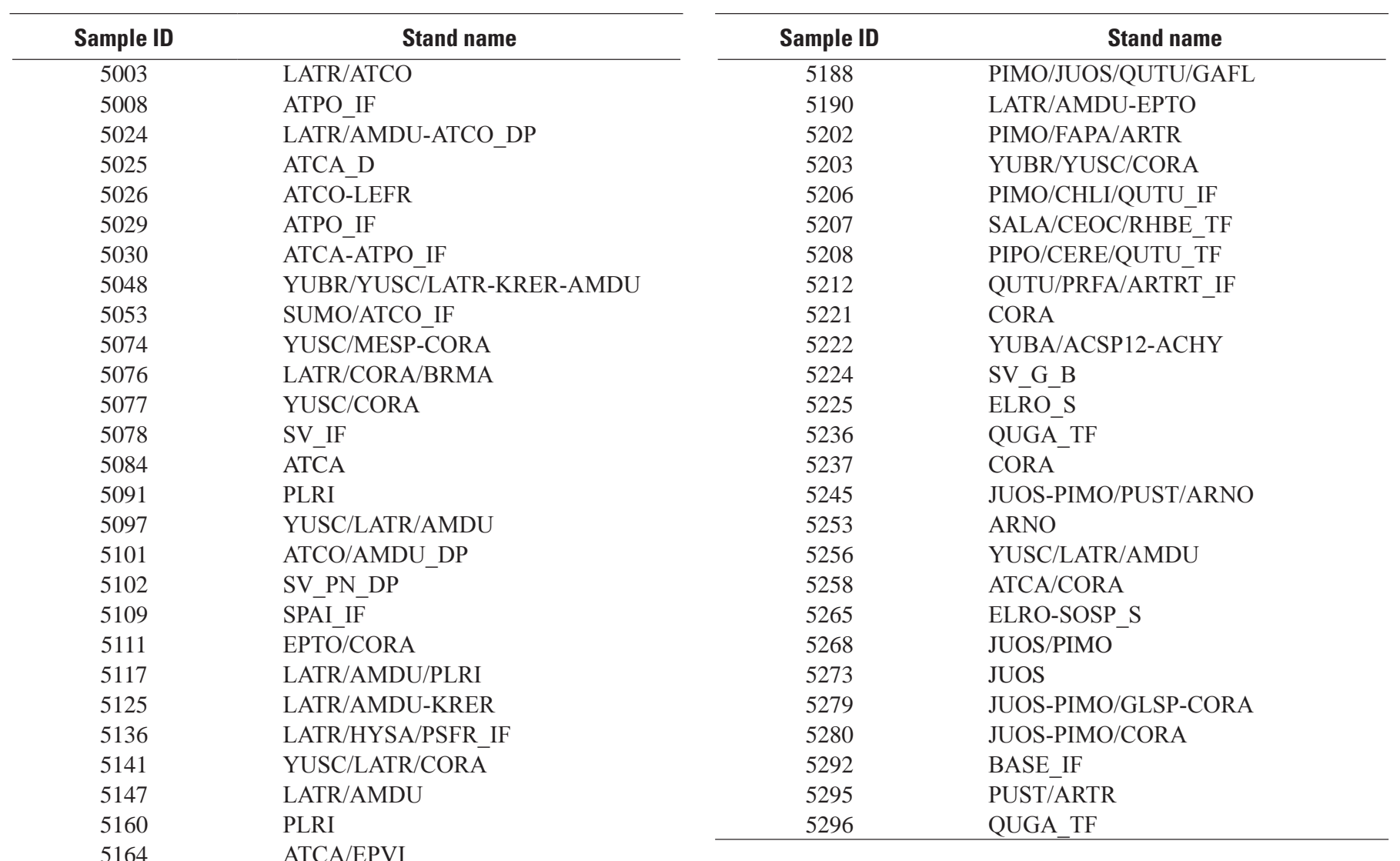


Table 2-2. Field samples from Mormon Mesa Area of Critical Environmental Concern used as training input for Feature Analyst automated feature extraction models.

[Source: Charlet, D.A., Leary, P.J., and Damar, N.A., 2014, Vegetation database for land-cover mapping, Clark and Lincoln Counties, Nevada: U.S. Geological Survey, Data Series 827, 17 p., http://dx.doi.org/10.3133/ds827: Sample ID, Unique number used to identify sample in field sample database; Stand name, Descriptor for sample based on dominant species in each canopy layer.]

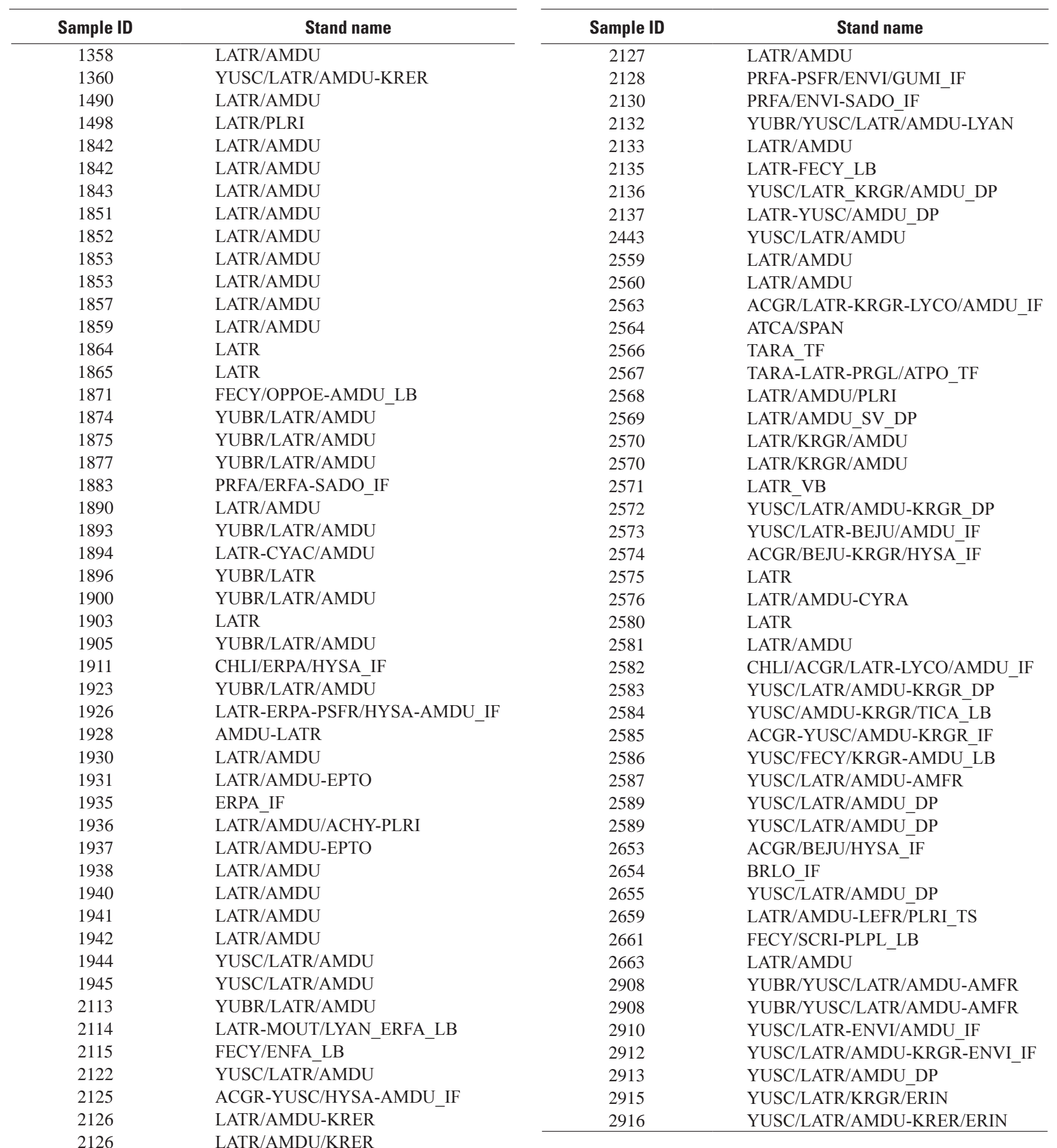


Table 2-3. Field samples from Coyote Springs Area of Critical Environmental Concern used as training input for Feature Analyst automated feature extraction models.

[Source: Charlet, D.A., Leary, P.J., and Damar, N.A., 2014, Vegetation database for land-cover mapping, Clark and Lincoln Counties, Nevada: U.S. Geological Survey, Data Series 827, 17 p., http://dx.doi.org/10.3133/ds827: Sample ID, Unique number used to identify sample in field sample database; Stand name, Descriptor for sample based on dominant species in each canopy layer.]

\begin{tabular}{cl}
\hline Sample ID & \multicolumn{1}{c}{ Stand name } \\
\hline 338 & LATR/AMDU \\
341 & LATR/AMDU/ERTR \\
343 & YUSC/LATR/AMDU/PLRI \\
345 & YUSC/LATR-PSFR/AMDU-KRER \\
346 & YUSC/LATR-PSFR/AMDU-ACSH \\
347 & YUSC/LATR-PSFR/AMDU \\
347 & YUSC/LATR-PSFR/AMDU \\
1361 & YUSC/LATR-PSFR/KRER-AMDU \\
1363 & YUSC/LATR/KRER-OPPOE \\
1364 & AMDU \\
1365 & CHLI/CHVI_IF \\
1365 & CHLI/CHVI_IF \\
1394 & LATR/AMDU \\
1395 & YUSC/LATR-AMDU \\
1396 & AMDU/BAMU-SPAM \\
1398 & LATR/LYAN-ATCA \\
1407 & PRGL/ATCA_SF \\
1527 & LATR/AMDU \\
1529 & LATR/AMDU \\
1532 & YUBR/LATR-YUSC/AMDU/PLRI \\
2140 & LATR \\
2151 & YUSC/PRFA-MOUT/BUUT-SADO_LB \\
2490 & LATR/AMDU \\
\hline
\end{tabular}


Table 2-4. Field samples from Piute-Eldorado Valley Area of Critical Environmental Concern used as training input for Feature Analyst automated feature extraction models.

[Source: Charlet, D.A., Leary, P.J., and Damar, N.A., 2014, Vegetation database for land-cover mapping, Clark and Lincoln Counties, Nevada: U.S. Geological Survey, Data Series 827, 17 p., http://dx.doi.org/10.3133/ds827: Sample ID, Unique number used to identify sample in field sample database; Stand name, Descriptor for sample based on dominant species in each canopy layer.]

\begin{tabular}{|c|c|c|c|}
\hline Sample ID & Stand name & Sample ID & Stand name \\
\hline 168 & LATR/AMDU & 1226 & YUSC/LATR/AMDU \\
\hline 178 & YUBR/LATR/CORA & 1228 & LATR/AMDU \\
\hline 179 & YUBR/YUSC/LATR/CORA & 1229 & LATR/AMDU \\
\hline 185 & YUSC/LATR/ACSPS2 & 1240 & LATR/AMDU \\
\hline 187 & YUSC/LATR/EPTO/ACSPS2-AMDU & 1241 & LATR/AMDU \\
\hline 188 & YUSC/LATR/AMDU & 1241 & LATR/AMDU \\
\hline 194 & LATR/AMDU & 1258 & LATR/AMDU \\
\hline 197 & LATR/AMDU-SEAR & 1258 & LATR/AMDU \\
\hline 240 & CHLI/ACGR/PHCA/HYSA-SEAR_IF & 1259 & YUSC/LATR/HYSA-AMDU \\
\hline 249 & LATR/AMDU & 1265 & YUSC-NOBI/ERFA \\
\hline 250 & LATR/AMDU & 1266 & YUSC/LATR/AMDU \\
\hline 250 & LATR/AMDU & 1271 & LATR/CORA \\
\hline 253 & ACGR/PHCA/HYSA-SEAR_IF & 1274 & LATR/AMDU \\
\hline 258 & ACGR/PHCA_IF & 1287 & YUSC/LATR/ERFA \\
\hline 276 & YUSC/LATR & 1791 & LATR/AMDU \\
\hline 292 & ACGR/PHCA/ERPA-BRIN_IF & 1828 & YUSC/LATR-AMDU-ERFA \\
\hline 297 & YUBR/LATR/AMDU & 1964 & LATR/SEAR/AMDU \\
\hline 309 & ACGR/HYSA-ERPA-AMER & 1970 & YUBR/LATR-YUSC/KRLA-KRER \\
\hline 310 & YUBR/YUSC-YUBA/ACSPS2/PLRI & 1996 & YUSC/LATR/AMDU \\
\hline 311 & YUBR/YUSC/PLRI-GUMI & 1998 & YUSC/EPTO/ERFA-ERCO23 \\
\hline 328 & CHLI/ACGR/ERPA-AMER_IF & 1999 & ACGR/HYSA/ERFA IF \\
\hline 330 & YUSC/LATR/ERFA & 2072 & LATR-EPTO/AMDU \\
\hline 332 & YUSC/EPTO-LATR/PLRI & 2073 & ACGR/HYSA-EPTO/ERFA-SADO_IF \\
\hline 333 & YUSC/LATR/ERFA-AMDU & 2088 & EPNE/SPAM/DAPU-ARPUP6 \\
\hline 1220 & LATR/PLRI & 2089 & YUBR/LATR-YUSC-CYAC/CORA- \\
\hline 1221 & ERPA IF & & YUBA-EPNE \\
\hline 1222 & LATR/PLRI & 2454 & LATR-ACGR-YUSC/AMDU-ERFA \\
\hline 1225 & LATR/AMDU & 2631 & PICA/YUBR/PUGL/CORA \\
\hline
\end{tabular}


Prepared by the Sacramento Publishing Service Center.

For more information concerning this report, contact:

Director

U.S. Geological Survey

Nevada Water Science Center

2730 N. Deer Run Rd.

Carson City, NV 89701

dc_nv@usgs.gov

Or, visit our Web site at:

http://nevada.usgs.gov/water/ 

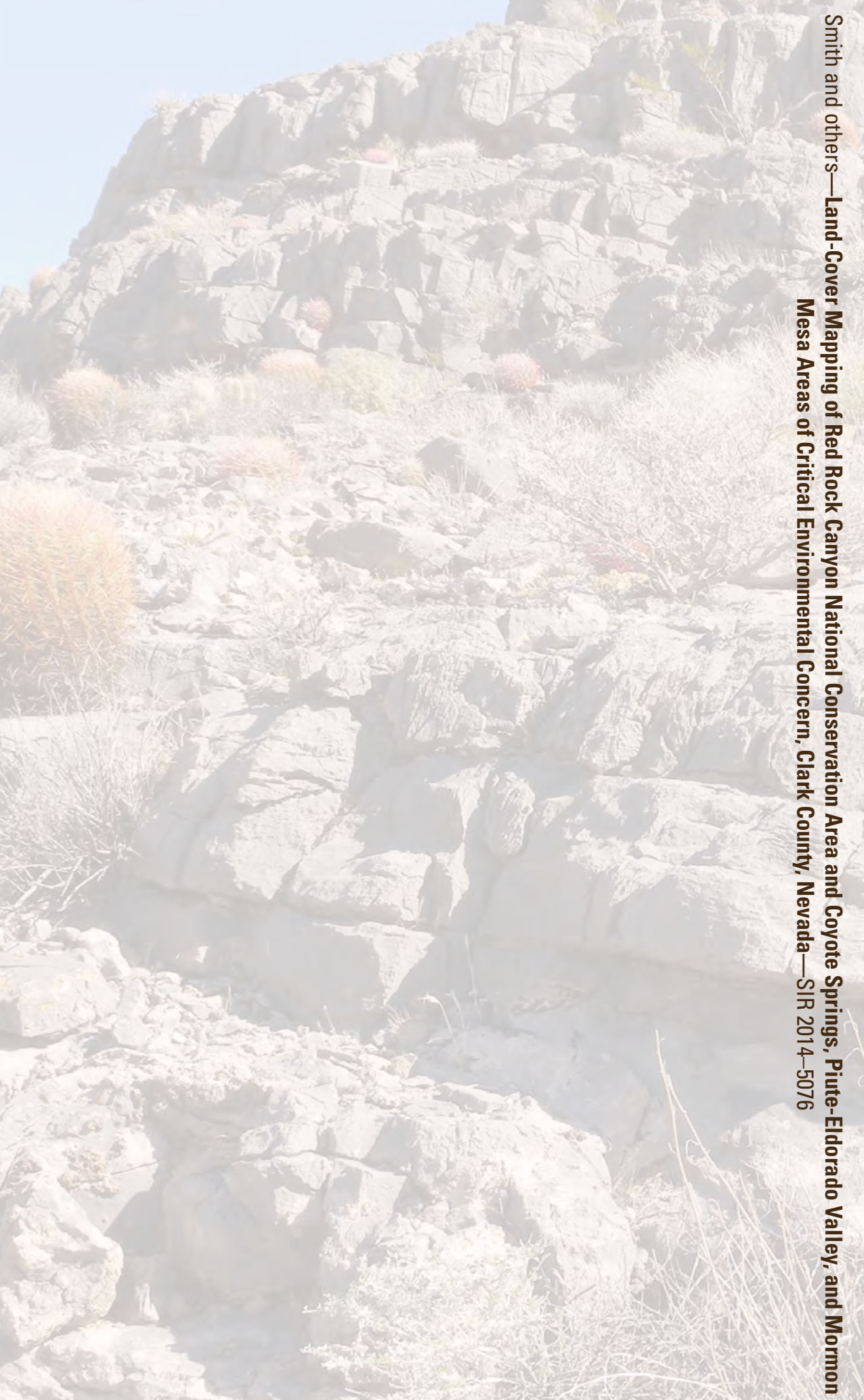